\title{
9 The age of the artes liberales
}

\$1 For the history of Latin science there are good reasons to consider later Antiquity and the Early Middle Ages ${ }^{1}$ before the introduction of Greek science in the twelfth century as one single period. Within this time span, scientific and scholarly writers shared important characteristics, most conspicuously the scheme of the artes liberales for addressing advanced learning. Other points include the fact that they were mostly Christians, which entailed some changed attitudes toward language, learning, and society in general compared to their pagan predecessors. For example, the Christian attitude toward manual work was much less elitist than that of Graeco-Roman pagan intellectuals; consequently, the separation between theoretical and practical science is less clear-cut. ${ }^{2}$ In terms of science, this epoch has been called 'l'ère des manuels et des résumés' ('the era of manuals and résumés'; Hadot 1955: 235). This is especially true for sciences of little or no practical use, such as the mathematical and natural sciences. ${ }^{3}$ The scientific background is more Platonist than Aristotelian. Knowledge of Greek became rarer in later Antiquity, even among the most educated Romans - a typical example is $\mathrm{Au}$ gustine, who read Greek badly at best - thus, the influx of Greek innovation also dried up. The Liberal Arts (artes liberales) are the usual umbrella term for the sciences widely taught at schools through this epoch. ${ }^{4}$ They are called 'liberal' be-

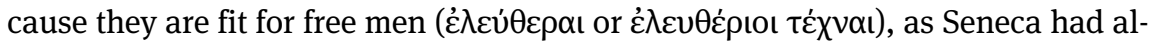
ready held (Epistola 88.2, ed. Stückelberger, p. 84):

\begin{abstract}
quare liberalia studia dicta sint, vides: quia homine libero digna sunt. ceterum unum studium vere liberale est: quod liberum facit, hoc est sapientiae, sublime, forte, magnanimum. cetera pusilla et puerilia sunt.

'You see why they are called "Liberal Arts": because they are worthy of a free man. Otherwise, there is only one study that is really "liberal", viz. that makes free, and that is the study of wisdom; it is exalted, strong, magnanimous, all the others are trifles and childish.'
\end{abstract}

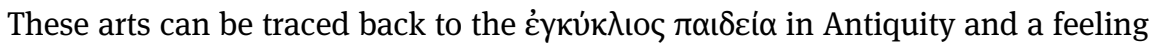
that all sciences form a single whole. ${ }^{5}$ The concept thus goes back to the preced-

1 For a century-by-century characterisation of the literature and thought of sixth to the fifteenth century, see Leonardi (2002).

2 As Hägermann \& Schneider (1991: 323) rightly point out.

3 A detailed list of scientific writers from Late Antiquity can be found in Hadot (1984: 253-260). For knowledge of Greek, see Courcelle (1948).

4 For details see D’Alverny (1946). See also Riché (1962), and esp. Hadot (1984). For an introduction to the artes liberales, see Christes (1996).

5 On which see Hadot (1984: chap. 6). 
ing epoch, but it is only in Augustine's De ordine that their sevenfold canon can be observed with certainty for the first time, ${ }^{6}$ yet even in later works by Augustine, this sevenfold classification is not upheld: in De doctrina christiana, several sciences studying perishable nature are named together with the seven. ${ }^{7}$ In earlier authors, we find deviant lists of 'free' artes. Varro, for instance, did treat at least some of the seven in his lost De disciplinis, but he also includes medicina and architectura (see chap. $8 \S 5$ above). ${ }^{8}$ Typically for Platonism, the Liberal Arts do not comprise studies of perishable things (as physics, medicine, or biology do); thus, they fit in well with the Platonic turn in mediaeval Latin philosophy before the twelfth century: the Seven Arts are propaedeutic not so much for philosophy in general as for Platonic philosophy (Hadot 1984: 132). Among these seven disciplines, three deal with language and man's use of it (out of which the human sciences would develop), and were known as the trivium in the Middle Ages.

- Grammatica studied words, parts of speech, and kinds of phrases and sentences. It can also be seen as an ancestor of our linguistics, and it can even include the scientific study of history (historia). ${ }^{9}$

- Dialectica was the art of argumentation, kinds of statements, syllogisms, and so on, which developed into logic. In the Middle Ages, dialectica was mostly studied using Boethius' translations of Aristotle's Organon (lacking the Analytica posteriora).

6 Hadot (1984: chap. 4).

$7 \mathrm{He}$ is arguing that animalium, herbarum, etc., praesertimque siderum cognitio as well as the mechanicae artes are useful to understanding of Scripture (cf. chapter headings 29 and 30 in the PL edition). This point is made by Hadot (1984: 136).

8 Hadot (1984: chaps 3-4) develops the details of the formation of this canon. Greek authors also

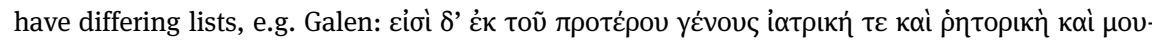

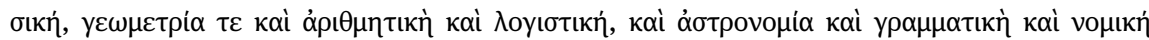
('There are among the former [i.e. the non-physical, "liberal"] arts: medicine, rhetoric, music, geometry, arithmetic, practical arithmetic, astronomy, grammar, and law'; Adhortatio ad artes addiscendas 14, ed. Kühn, vol. 1, p. 39) - thus adding medicine and law to the usual seven.

9 Augustine states: Poterat iam perfecta esse grammatica sed, quia ipso nomine profiteri se litteras clamat - unde etiam Latine litteratura dicitur - factum est, ut, quidquid dignum memoria litteris mandaretur, ad eam necessario pertineret. itaque unum quidem nomen, sed res infinita multiplex curarum plenior quam iucunditatis aut ueritatis huic disciplinae accessit, historia non tam ipsis historicis quam grammaticis laboriosa ('Grammar could now be complete, but as by this name "letters" are addressed - whence Latin litteratura - it happens that everything worth remembering and that is written down necessarily also belongs to grammar. Thus, a single name was given to this discipline, but the matter is an infinite multitude fuller of worries than delight or truth, history being laborious not only to historians but also to grammarians'; De ordine II.12(37), ed. Doignon, p. 274). Similarly already Quintilian (Institutio oratoria I.8.18, ed. Rahn, vol. 2, p. 122). 
- Rhetorica was originally intended to train students for speeches, especially at court. As such, it is akin to jurisprudence (focusing on oratory). In studying figures of thought and of speech, it is also related to modern literary studies.

For all of them, the main method in the Middle Ages was the study of classical Latin texts. Apart from these linguistic arts, the artes liberales comprise the four mathematical sciences. Boethius originally coined the term quadruvium for them,

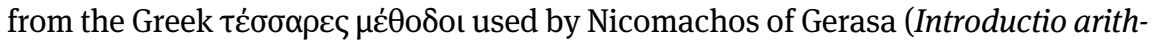
metica I.4, ed. Hoche, p. 9), who explained their topics as:

- $\quad$ arithmetica, studying discrete, unmoved quantity;

- geometria, continuous, unmoved quantity;

- $\quad$ musica (i.e. harmonics), discrete, moving quantity (tones);

- astronomia (usually including astrology), continuous, moving quantity (the heavenly bodies). ${ }^{10}$

Thus, they all study quantity and were strongly based on mathematics. These four sciences had already been mentioned and stressed as important for teaching by Plato (Respublica VII, 520-540). The first two would now be subsumed under mathematics, the last two under mathematical physics. The sevenfold number of these arts, in a Christian environment, nicely fits the biblical passage (Prov. 9:1):

Sapientia aedificavit sibi domum, excidit columnas septem.

'Wisdom built for itself a house, it hewed out seven columns.'

The Seven Arts became the usual classification of the disciplines in the Early Middle Ages through the influential works of Augustine, Martianus, and Cassiodorus, and were taught in school at least from Carolingian times onward, although the mathematical sciences were not - with a few exceptions (especially in computus) - cultivated much beyond basic school learning. ${ }^{11}$ Their naming as artes is somewhat surprising, as they lack the practical aim of producing an opus; but as pointed out above (chap. $3 \S 4$ ), the term ars can be synonymous with disciplina and scientia. It has also been stressed (chap. 1 \$1) that Cassiodorus called some of these branches of learning artes and others disciplinae. In his Institutiones, rhetoric and grammar are among the former, and the mathematical

10 This scheme of dividing the quadruvial arts using movement and continuity was common. For example, it is also used by Proclus, In Euclidem prol. 1, ed. Friedlein, pp. 35-36.

11 On the study of these mathematical fields in the Middle Ages, see Englisch (1994); Klinkenber (1959). On a different classification of philosophy/science in the Early Middle Ages, see Bischoff (1958). 
sciences among the latter. He is uncertain which kind dialectica (including logic) should belong to (praef. 4, ed. Mynors, p. 92). Thus, he comes close to our understanding of 'science', which would not include elementary grammar and rhetoric, either.

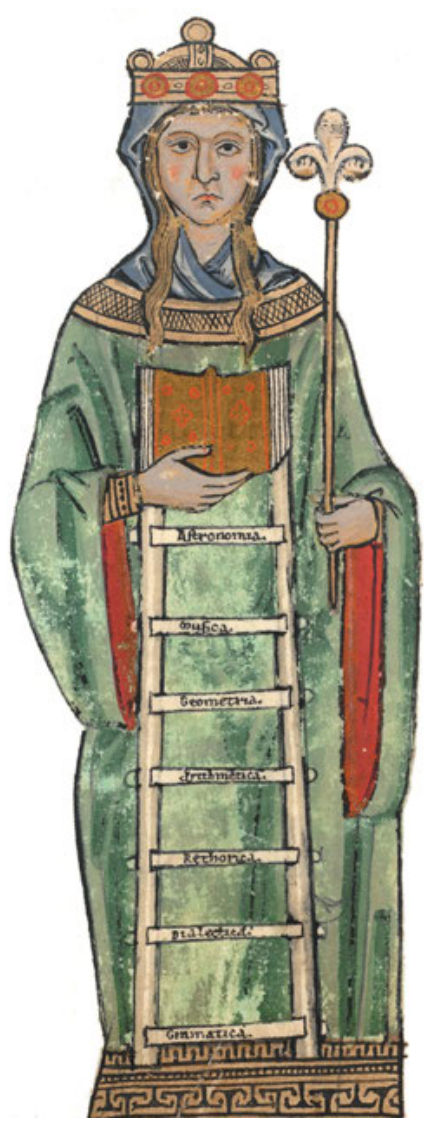

Fig. 13: Universitätsbibliothek Leipzig, Ms 1253, fol. 3r, a Boethius manuscript depicting Lady Philosophy with a ladder made up of the Liberal Arts. Reproduced with permission.

The Liberal Arts are also known as ingenuae disciplinae, by Cicero, for example, ${ }^{12}$ as yet without a clear canon, but even Cassiodorus and Isidore no longer understand the name: they take the word liberalis to refer to books (libri). ${ }^{13}$ This illus-

12 De finibus II.67, ed. Moreschini, p. 65.

13 Institutiones II, praef. 4, ed. Mynors, p. 91; Etymologiae I.4.2, ed. Lindsay. 
trates a shifting emphasis between the pagan and the Christian Denkstil, replacing aristocratic liberty with book learning. The canon remains largely unquestioned in the Middle Ages up to the translation movement in the twelfth century. ${ }^{14}$ These Seven Arts are often depicted symbolically in manuscripts, as in figure 13. Such a canon of Seven Liberal Arts was unknown in Byzantium, where education seems to have remained closer to Hellenistic ways, including grammar, rhetoric, philosophy (including the Organon), physics, the quadrivium, theology. ${ }^{15}$ Some mediaeval Latin authors try to construct seven corresponding mechanical or practical arts to counterbalance the seven theoretical ones. The name artes mechanicae occurs first in Firmicus Maternus, ${ }^{16}$ and Eriugena in his commentary on Martianus Capella suggests that there should also be seven of them. Hugh of St Victor finally proposes a list, albeit one that makes a rather ad hoc impression: ${ }^{17}$ lanificium, armaturam, navigationem, agriculturam, venationem, medicinam, theatricam.

Late Antiquity is often said to begin with Diocletian's reforms after AD 284 and the introduction of the Dominate, or alternatively with Constantine's adoption of Christianity (312). ${ }^{18}$ Many things change in the fourth century. Scholars and intellectuals in Late Antiquity were sometimes still active at the imperial court (as late as Boethius), while others will still have been private gentleman scholars (possibly Martianus Capella). But from the time of Cassiodorus onward, they tend to be monks and work in monasteries stocked with libraries. ${ }^{19}$ In addition to these, in the Early Middle Ages cathedral schools storing the knowledge of the past became important: both organisations were run by the Church and were most strongly interested in propaedeutic teaching manuals and theology - in keeping with Augustine’s De doctrina christiana (see $\$ 2$ below). In what follows, the typical ingredients of the Denkstil of the Liberal Arts in this epoch are considered: Christian scholarship (§2), Christian neo-Platonism (§3), the study and use of Latin (§4), the use of compendia on science and some important authors ( $\S 5-7$,

14 With very few exceptions, such as Eriugena, who doubts the canonical ordering and would, again, exclude the 'man-made' arts of rhetoric and grammar (Periphyseon PL 869D-870B, V.4, ed. Jeauneau, vol. 5, pp. 15-16).

15 See Praechter (1910), Browning (1963), and now Pérez Martín \& Manolova (2020).

16 Mathesis VI.30.26, ed. Monat, vol. 3, p. 83.

17 Didascalicon 3.1, ed. Offergeld, p. 216. On the artes mechanicae in the twelfth century, see Alessio (1984).

18 The first date is current among historians, as Diocletian restored order and stability in the Empire. The latter date marks the starting point of, for example, vol. 4 of Schanz \& Hosius (19221935).

19 For an introduction to mediaeval monasticism, see Lawrence (1992). 
11), and some historical developments concerning our subject during the main periods of the Early Middle Ages (§§8-10, 12).

\section{Scientific approaches among the Church Fathers}

\$2 No Christian authors have been treated as yet, so we must move back in time, as Christianity developed intellectually in the Graeco-Roman milieu discussed in the previous chapter. At least from the late second century onward, Christianity began to absorb the philosophical backgrounds of its surroundings, which were first Stoic, then (and foremost) neo-Platonist. ${ }^{20}$ Like the former, Christian authors emphasised the practical importance of improving one's soul; like the latter, they held theology to be the most important 'science', its goal being to determine scientifically the nature of the Godhead and its rapport with world and soul. The lower reaches of the world inhabited by us ('nature') were clearly of secondary importance; the most important sciences besides theology were the mathematical, non-material ones - a state of affairs that Christians took over and that was to last until the twelfth century. The methods the early Christian theologians employed were (biblical) scholarship and discussions between leading spiritual authorities, apparently based on experience in their own spiritual lives and those of their flocks. Many of the deepest thoughts in this field were expressed in Greek (especially by the Alexandrian and Cappadocian Fathers), but here the Latin literature is also considerable.

The Roman ideals of language and rhetoric and of philosophical and scientific plausibility came to be largely shared by intellectual Christians, and they proved useful for missionary activities among intellectual pagans. It may be objected that these Christian authors were not 'disinterested' and thus disqualified as scientists, but the same can be said about practically all Roman authors studied in the previous chapter. Some were more interested in the art of speaking; others were also missionaries, albeit for their own philosophico-religious systems: the Epicurean Lucretius or the Stoic Seneca resemble the Christian Augustine in this respect rather closely. Soon some of the Christians also wrote scholarly or philosophical treatises that had little or nothing to do with religion. In their own Scriptures, Christians could learn the importance of scientia from Isaiah 11:2-3:

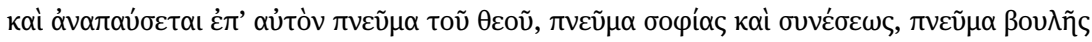

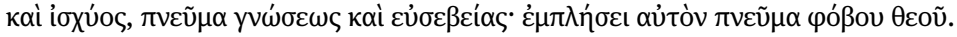

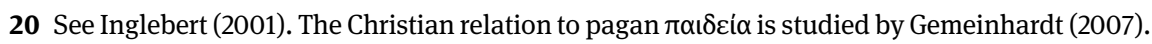


Et requiescet super eum spiritus Domini: spiritus sapientiae et intellectus, spiritus consilii et fortitudinis, spiritus scientiae et pietatis, et replebit eum spiritus timoris Domini.

'And the Spirit of the Lord shall rest upon him: the Spirit of wisdom, understanding, counsel, fortitude, science and piety, and the spirit of fear of the Lord shall fill him.'

So, scientia was one of these Seven Gifts of the Holy Spirit in the Latin form of the

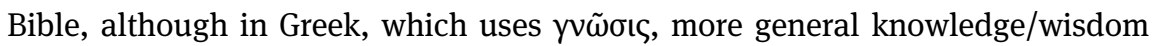
seems to be intended (in keeping with the original Hebrew $\left.d a^{\prime} a t\right) .{ }^{21}$ This passage became important to Latin Christian theologians and was often commented.2. It will be seen in chapter 11 how Aquinas argues that theology - at least in its scholastic form - is a scientia. Other biblical passages also seemed to encourage natural science. ${ }^{23}$ Thus, we can speak of a Latin Christian Denkstil which had imported a lot from Greek Denkstile, although only to some degree its most scientific (Aristotelian) constituents. This combination proved lasting and stable, although not very conducive for innovative science. The four most important early Latin writers in our context are now briefly introduced.

Quintus Septimius Florens Tertullianus (ca. 160-ca. 225) may not count as a scientist in even the broadest sense, even if we concede that Christian theology can be a scientia, but his language is of great importance in the present context. ${ }^{24}$ Although Tertullian was the first Christian writer who wrote 'serious' theology in Latin (not in Greek), he was more of an ecstatic and mystic than a scholar. He does not hide his disdain for philosophy and learning outside Christianity; he is famous for his rhetorical question Quid ergo Athenis et Hierosolymis? ('What does Athens have to do with Jerusalem?'; De praescriptionibus haereticorum 7, ed. Refoulé, p. 193) ${ }^{25}$ In order to express his extravagant new ideas, he often introduced daring novelties into his language, which has aptly been termed a Flammensprache (Norden 1958: 2:606). Among his many new words, the most success-

21 A similar case is found in Hosea 4:6: Conticuit populus meus, eo quod non habuerit scientiam: quia tu scientiam repulisti, repellam te [...] ('My people have become silent as they lacked knowledge [scientia], because thou hast rejected knowledge, I shall reject thee [...]'). Again Greek uses yvũoıs, Hebrew da'at.

22 Hugh of St Victor, for instance, was to write an entire treatise on these Seven Gifts (De septem donis spiritus sancti, ed. Siri).

23 Famously, Wisdom 11:21: sed omnia in mensura, et numero et pondere disposuisti ('but Thou hast disposed everything by measure, number, and weight').

24 e.g. '[...] welche entscheidende Stelle Tertullian in der Geschichte des christlichen Lateins einnimmt' ('[...] what a decisive position Tertullian occupies in the history of Christian Latin'; Demmel 1944: 129).

25 Instead, he advocates (in the next sentence) simplicitas cordis. 


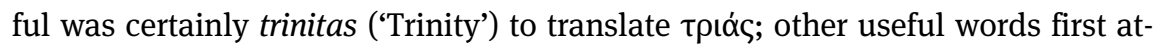

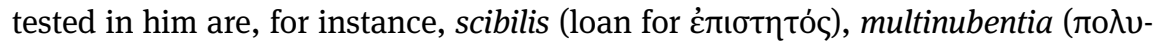

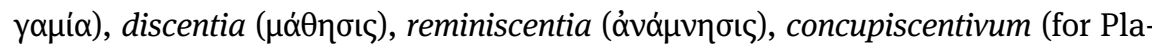

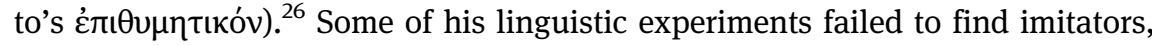
such as baptizator instead of baptista. Some others, such as scibilis, become frequent only much later (in this case in Aquinas or Lullus). His language is idiosyncratic; he uses some Latin words with meanings known only from him, for instance expungo as 'fulfil' and 'record'. ${ }^{27}$ But his language is also full of Greek syntactic influences, for instance in the use of participles and infinitives. ${ }^{28}$ Tertullian's often daring style, full of neologisms and similar to that of Apuleius, has to be seen in conjunction with the Second Sophistic. Von Albrecht points out: 'Damals entsteht die lateinische Sprache der Theologie; sie wird zur Mutter der neueren Philosophie' ('It was then that the Latin language of theology was born; it was to become the mother of modern philosophy'; 1992-1994: 2:1222). A passage from De anima (57, ed. Waszink, p. 76) will illustrate his language:

Quid ergo dicemus magian? quod omnes paene, fallaciam. Sed ratio fallaciae solos non fugit Christianos, qui spiritalia nequitiae, non quidem socia conscientia, sed inimica scientia novimus, nec invitatoria operatione, sed expugnatoria dominatione tractamus multiformem luem mentis humanae, totius erroris artificem, salutis pariter animaeque vastatorem; sic etiam magiae secundae scilicet idololatriae, in qua se daemones perinde mortuos fingunt, quemadmodum in illa deos.

'What will we, then, call magic? Like most men: an imposture. But it is a kind of imposture that only we Christians do not fail to recognise. We alone have uncovered these spirits of evil, not indeed by having been their accomplices, but by a science hostile to them. Not by any procedure attracting them, but by overpowering dominion, we treat that manifold plague of the human mind, that artificer of all error, devastator of both salvation and soul; also that of the second kind of magic, of idolatry, in which demons pretend to be defunct people, similarly as in the other gods.'

His special language has been studied in detail. ${ }^{29}$ Braun (1977: 547-548) provides a list of terms that are quite certainly his invention:

26 Other examples in Springhetti, Latinitas fontium, p. 28. His predilection for -entia/-antia was studied by Demmel (1944), who finds thirty-six such neologisms (129).

27 See the entries in Lewis \& Short and Georges. Further examples are provided by Norden (1958: 2:607). Teeuwen (1926) studied these cases.

28 Examples in Norden (1958: 2:608-609).

29 On his innovative language, see e.g. Löfstedt (1920); Braun (1977); Fredouille (1992); Wellstein (1999). 
conspector, dispector (despector), factitator, potentator, restitutor, resurrector, resuscitator, reuelator, salutifactor, sanctificator, suscitator, uiuificator; apparentia, impraescientia, improuidentia; factitamentum; factitatio, figulatio (18 nouns);

inadprehensibilis, incongressibilis, incorporabilis, inconuertibilis, indemutabilis, informabilis, innascibilis, inreformabilis, nascibilis; corruptorius, incorruptorius, reuelatorius; monarchianus; substantiualis (14 adjectives);

figulare, unare (2 verbs).

Many of them are certainly Augenblicksbildungen (as Braun points out). More examples are cited in Wellstein (1999: 94), including interesting compounds such as duricordia or munditenens. On the whole, Tertullian's casual approach to coining new words provided much Christian Latin vocabulary and inspired some authors in the Middle Ages to behave similarly, although most Christian Latin authors did not go to such extremes, especially not the rhetorically minded Fathers like Lactantius or Augustine. Many of the post-classical words quoted in the appendix of this book are first attested in Tertullian.

In contrast to Tertullian, Aurelius Augustinus (354-430) did write scholarly works not directly concerned with Christian matters. Before his conversion to Christianity, he lived a rather worldly life as an orator, and he was clearly interested in learning in general. ${ }^{30}$ Augustine treats the Liberal Arts in order to prepare for the one supreme science: theology. Already in his early dialogue De ordine, where he considers how order in the world comes about, he stresses the importance of these Liberal Arts (I.24, ed. Doignon, p. 126):

\begin{abstract}
Nam eruditio disciplinarum liberalium modesta sane atque succincta et alacriores et perseuerantiores et commotiores exhibet amatores amplectendae ueritati, ut et ardentius adpetant et constantius insequantur et inhaereant postremo dulcius, quae uocatur, Licenti, beata uita.

'For sober and mentally prepared study of the liberal sciences makes lovers of truth more alacritous, persevering, and passionate, so that they strive for and unwaveringly seek and finally cling more tenderly to, Licentius, what is called the blessed life.'
\end{abstract}

But later in his life, in his Retractationes, Augustine points out that Christian virtue is more important than scientific learning, which he came to believe he had overrated in his youth (I.3.2-4, ed. Knöll, pp. 19-20):

Verum et his libris displicet mihi [...] quod multum tribui liberalibus disciplinis, quas multi sancti multum nesciunt, quidam etiam sciunt et sancti non sunt.

'Indeed, I dislike in these books [...] that I allotted much importance to the liberal sciences, which are unknown to many a saint, but others know them and are no saints.'

30 On Augustine's relation to worldly science, see Porro (2001: 130-133). 
In his early period Augustine was strongly influenced by neo-Platonism, and he brought its way of thinking into Latin Christianity. In his youth, Augustine planned to write on all the Liberal Arts. He left a didactic dialogue, De musica, between a magister and a discipulus (a genre that was to be very successful in the Middle Ages), and an unfinished De dialectica. ${ }^{31}$ This latter work is presented as a rather elementary introduction in simple style. It commences (ed. Pinborg, p. 83):

Dialectica est bene disputandi scientia. Disputamus autem utique verbis. Verba igitur aut simplicia sunt aut coniuncta.

'Dialectics is the science of debating well. We debate with words. Words are either univocal or equivocal.'

Augustine's usual style is very different: in many of his works, a tension between the orator and the Christian preceptor who wants to be understood by simple and erudite people alike can be felt. Symptomatic of this is his statement (Enarrationes in Psalmos Ps. 36, sermo 3.6, ed. Dekkers \& Fraipont, vol. 1, p. 371):

Melius in barbarismo nostro vos intelligitis, quam in nostra disertitudine uos deserti eritis.

'It is better that you understand our barbarian way of talking than that you get lost in our erudition.'

This advice is formulated in a highly rhetorical manner with the word play disertitudine [...] deserti eritis. For Augustine's epistemology, the most important work is certainly De doctrina christiana. In this work (II, 13(20), ed. Green, pp. 46-47), while commenting on Psalm 32:12: Beata gens, cuius est Dominus Deus eius ('Happy the people whose Lord is its God'), ${ }^{32}$ Augustine emphasises that a sermo humilis bordering on incorrect Latin syntax is not to be rejected in the context of the Bible. In the same work, he develops a philosophical theory of signa, a predecessor of modern semiotics. Although the primary aim is to teach biblical hermeneutics, his approach can be used quite generally. The first three books discuss inventio of what is to be understood, the fourth and final one its modus proferendi (I.1, ed. Green, p. 8). Inventio leads Augustine to the famous dictum (II.144-145, p. 75):

Philosophi autem qui vocantur, si qua forte vera et fidei nostrae accommodata dixerunt, maxime Platonici, non solum formidanda non sunt, sed ab eis etiam tamquam iniustis possessori-

31 The introduction to the edition by Jackson convincingly shows by traditional and quantitative methods that the attribution to Augustine is very likely correct.

32 Stotz (forthcoming) writes that this passage is 'one of the loci classici in the discussion on faithful translation, sermo humilis and linguistic correctness'. 


\begin{abstract}
bus in usum nostrum vindicanda. $[. . .]^{33}$ sic doctrinae omnes gentilium non solum simulata et superstitiosa figmenta gravesque sarcinas supervacanei laboris habent quae unusquisque nostrum duce Christo de societate gentilium exiens debet abominari atque devitare, sed etiam liberales disciplinas usui veritatis aptiores.

'The so-called philosophers, especially the Platonists - if perchance they say something true and conforming to our Faith, it is not only not to be feared, but it is to be appropriated as if from unlawful possessors. [...] thus, all teachings of the pagans not only contain counterfeited and superstitious figments and grave burdens of superfluous labour, which every one of us exiting from the company of the pagans, led by Christ, has to abhor and avoid, but there are also the Liberal Arts, which are rather apt for the use of finding truth.'
\end{abstract}

Like the pagan orator Quintilian, Augustine stresses the importance of general erudition, but he goes much further in his conception of an accomplished scholar; indeed, the following words could be used to describe much of the modern philological method (III.1, p. 79):

[...] praemunitus etiam scientia linguarum, ne in verbis locutionibusque ignotis haereat, praemunitus etiam cognitione quarumdam rerum necessariarum, ne vim naturamve earum quae propter similitudinem adhibentur ignoret, adiuvante etiam codicum veritate, quam sollers emendationis diligentia procuravit, veniat ita instructus ad ambigua scripturarum discutienda atque solvenda.

'[A man loving God and seeking to understand Scripture] should come fortified with the knowledge of languages [Hebrew, Greek], in order not to stick to unknown words and locutions; he should also come fortified with the knowledge of some necessary [historical and scientific] facts, in order not to miss the force and nature of things that are employed for their similarity [to something else]. In this, the truthfulness of the manuscripts will also help, which skilful care in emendation has taken care of. He should come thus instructed in order to discuss and solve the Scriptures' ambiguities.'

For Augustine scientia and sapientia are the higher goals of the mental exercitatio consisting of a Christian life and Christian studies. ${ }^{34}$ Such 'science' has only limited common ground with 'worldly' science. Both Augustine's style and (ambiguous) approach to worldly science will become paradigmatic during the Middle Ages prior to the twelfth century. His influence on intellectual life in general in the Latin-speaking world can hardly be overestimated.

There are also some spurious surviving works that treat scientific matters in particular, a shortened translation of Aristotle's Categoriae with important new vocabulary which, although not by Augustine, was probably written in his

33 In between, Augustine 'proves' this point by quoting Exodus (3:21-22, 12:35-36) where God tells the Israelites to purloin from the Egyptians what is valuable.

34 Details in Cardelle de Hartmann (2018: 78-80). 
time. ${ }^{35}$ The translator often adds the Greek word to make sure his Latin terms are

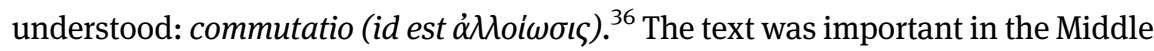
Ages as a logic primer. For instance, the Carolingian scholar Alcuin used it for his own De dialectica.

Augustine's contemporary Eusebius Sophronius Hieronymus (ca. 345420), known as Jerome in English, is of interest in the present context mainly as the translator of the standard Latin Bible, in early modern times to be called the (editio) vulgata, ${ }^{37}$ whose language was to become highly influential. He spent much of his life in the East and mastered Greek and Hebrew very thoroughly. This, together with an excellent Latin style, made him an ideal translator of the Bible into Latin and provided him with the basis for further scientific study, as Fürst (2016: 62) points out:

eine gediegene Ausbildung, eine umfangreiche Bibliothek, ausgezeichnete Beziehungen zu einflussreichen Leuten vor allem in Rom sowie Sprachkenntnisse. Im Blick auf diese materialen Grundlagen theologischen Arbeitens ist Hieronymus als Wissenschaftler zu beschreiben, der einen vorrangigen Platz in der europäischen Wissenschaftsgeschichte beanspruchen darf.

'a solid education, an extensive library, excellent relations with influential people, especially in Rome, and language skills. In view of these material foundations for theological work, Jerome is to be considered a scientist who can claim a prominent place in the history of European science.'

Besides the Bible translation, he wrote many biblical commentaries and other scholarly works. Because of the Bible's holiness, Jerome, although convinced that verbum de verbo translation should in general be avoided, chose to translate in a rather verbatim manner (Epistola 57.5, ed. Labourt, vol. 3, p. 59):

Ego enim non solum fateor, sed libera uoce profiteor me in interpretatione Graecorum absque scripturis sanctis, ubi et uerborum ordo mysterium est, non uerbum de uerbo, sed sensum exprimere de sensu.

'For I do not only admit but loudly proclaim that I do not formulate by the word-for-word method when translating from Greek (except for the Holy Scriptures, where even the order of the words is a mystery), but rather sense for sense. 38

Although he translated nearly the entire Bible text afresh - the Old Testament directly from the Hebrew - Jerome did not depart too far from the language of the

35 Thus Minio-Paluello in Aristoteles Latinus 1.1-5, p. lxxviii. The author may have been an otherwise unknown Albinus.

36 Ed. in Aristoteles Latinus 1.1-5, p. 174.

37 On biblical Latin in general, see Stotz (forthcoming).

38 More on his way of translating in Fürst (2016: 92-95). 
earlier Latin translations, in order not to estrange Christians who were familiar with them. ${ }^{39}$ Kaulen (1904) and Plater \& White (1926) studied the Vulgate's language, which differs quite strongly from Classical Latin, and provide among other things lists of unusual vocabulary found in it. Many words with the suffixes -tio (-sio) and -tor (-sor)/-trix ${ }^{40}$ are conspicuous. Some examples: eruditor, exasperatrix, exquisitor, fornicator, habitatrix (Kaulen 1904: 84). Kaulen found the following unusual true compounds: circumpes, inauris, malogranatum, multiloquium, seminiverbius, stultiloquium, vaniloquium (nouns; 97-98); animaequus, cornupeta, falsiloquus, longanimis, manufactus, multigenus, multivolus, omnimodus, pusillanimus, quadrangulatus, triennis, unigenitus, versipellis (adjectives; 151); beneplacere, parvipendere, putrefieri, tapefacere, valefacere, or even pessimare ('to make utterly bad') and manicare ('to come in the morning'; Luke 21:38) (verbs; 217-218). Of course, there are also many new words formed by suffixes, such as ieiunatio ('fasting'). Goelzer (1884: 130-134) lists further examples from other works of Jerome. There is a particularly large number of adjectives in -alis and -bilis. of course, Greek words are quite common, and Hebrew ones occur as well, the latter mostly as proper names. Goelzer (14-15) tries to list Jerome's neologisms and arrives at some 350, although he admits that it is usually impossible to say with any certainty who first used a word.

Christian Latin comes from the speech of humble Christians and was from the very beginning consciously popular and anti-rhetorical, a sermo piscatorius. But from Tertullian onward, there are Christian authors with rhetorical pretensions, albeit different ones than those of the pagan writers. Mohrmann (1955: 21-23) described the new vocabulary of this 'langue de groupe"41 and found three major types: new words for new Christian ideas and institutions (such as apostata, apostolus, baptisma); new abstract terms constructed following Greek models, often using suffixes (such as carnalis, spiritualiter, incarnatio, revelator); and new meanings for existing words (such as fides, caro, spiritus). This is the material with which Jerome worked. To some extent, this language drawn from life stands in conscious contrast to the rhetorical pagan Latin that early Christians will have seen as haughty, stiff, and dead. In several steps, Jerome improved existing Latin Bible translations, which were written in what might be called Christian spoken lower-class Latin. Although his result will have been less displeasing to an edu-

39 See Wick (2016) for more details.

40 See also Meershoek (1966) on this topic.

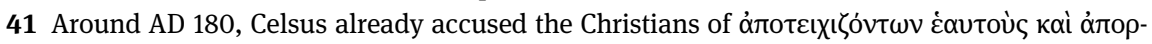

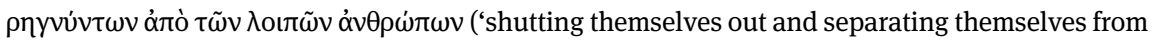

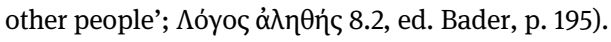


cated reader, it is still far from rhetorical Latin. Jerome kept Hebrew and Greek terms that had become common among Christians, such as sabatum, amen, cherubim, satan(as), alleluia, (h)osanna, zabaoth, but he also translated some of them; thus, the Lord of Hosts usually becomes dominus exercituum, no longer zabaoth. Greek words are still common, for instance apostolus, anathema, baptizare, blasphemare, clerus, diabolus, diaconus, ecclesia, elemosina, episcopus, evangelium, martyr, paracletus, presbyter, zizania, and many more. ${ }^{42}$ Latin words can have meanings unknown outside Christianity: redemptor ('contractor, undertaker, purveyor, farmer') comes to mean 'redeemer'; saeculum ('lifetime, race, age') becomes 'this world'; oratio ('speech') becomes 'prayer'; aemulator ('imitator') becomes 'zealot' (Deus est aemulator; Exod. 34:14), already attested in Tertullian; lacus leonum in Daniel 6:7 is a 'den, pit' not a 'lake, pond'. There are also syntactic Semitisms: Lot is Abraham's frater, here meant as 'relative' in general, in Genesis 14:16; anima mea stands quite often for mere ego, as in Hebrew napši; or magis plus adjective is used as a comparative. Cassiodorus was already aware of Jerome's importance for Christian Latin; he calls him Latinae linguae multiplicator egregius ('an eminent multiplier of the Latin language'; Institutiones I.5.4, ed. Mynors, p. 24). All the largely lower-class constituents of biblical Latin were thus ennobled and able to gain entrance into normal, written, 'fixed' Latin in all branches of life in the Middle Ages. Jerome's lasting influence on the Latin language was certainly a consequence of his Bible translation.

By Late Antiquity, translations from Greek had became important. ${ }^{43}$ Whereas in late republican and early imperial times, knowledge of Greek among Roman intellectuals was taken for granted, this was already much less the case in the time of Quintilian. McGuire (1959: 4) pointed out that Romans had become much less intimate with Greek literature because they now had their own classics. After the watershed of the third century, knowledge of Greek became much rarer. Augustine's 'limitations in Greek were not exceptional, but were generally typical at the beginning of the fifth century' (15). ${ }^{44}$ But the Latin language had progressively acquired much new terminology from Greek, all through Antiquity and in all intellectual fields. It has just been shown how strongly Christian Latin is indebted to

42 See further Stotz (1996-2004: IV, §§7-11 = vol. 1, pp. 519-542). In early modern times, some classicists, such as Sebastian Castellio (1515-1563), translate the Bible into Classical Latin without 'foreign' elements (see Stotz 2018).

43 Translations are listed in the ongoing Catalogus translationum (1960-) project. For a reasoned overview, see Berschin (1980: 105-108).

44 'There is no solid evidence for any real knowledge of Greek in Gaul after Sidonius and Gennadius [i.e. the end of the fifth century]' (McGuire 1959: 16). 
Greek. McGuire (25) concludes that 'the West had assimilated profane and Christian Greek thought and learning to an amazing degree'. Many theological and exegetical works were translated, but not much specialist science. Conversely, translations from Latin to Greek remained rare in general, and only become more common in the later Middle Ages in the two centuries before the fall of Constantinople. $^{45}$

Magnus Aurelius Cassiodorus Senator (ca. 485-ca. 585) can be seen as the founder of a paradigm of learning that proved to be stable and persistent, even in times of turmoil and war: the scholarly monk. ${ }^{46}$ This new form of small cells of Roman culture within a world of barbarian migrations preserved enough Roman culture for it to be rekindled later on, as Brown (1987: 8) stressed:

The monastery was a little world with a special culture all its own. Because it could expand to great numbers but also exist with very few, its culture was easily transplanted to a new cell in a new environment, where it could flourish independently, developing individual qualities and utilizing native talent.

After long pursuing in vain the idea of establishing a theological academy in Rome, Cassiodorus retired from his service at the court of the Gothic kings to found a monastery in Calabria called the Vivarium around 554. He gathered a significant library, and learned monks from the Greek East and the Latin West lived and studied there together. The monastery turned into a kind of theological university, apparently consciously imitating the Syrian school of Nisibis. ${ }^{47}$ Although his monastery did not seem to survive its founder for long, the idea of erudite monks who lived in monasteries with well-stocked libraries was to take hold, and the monastic library became a key feature of Latin monasteries. Cassiodorus' interests covered both Christian and secular studies, especially grammar and dialectic; he was aware of the importance of translation, especially from Greek. ${ }^{48}$ The

45 See Tinnefeld (2018).

46 There were some precedents. Strabo mentions monk-like scholars at the Alexandrian $\mathrm{Mu}$ -

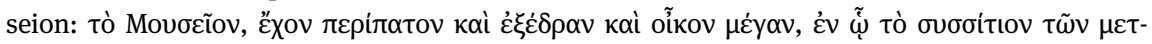

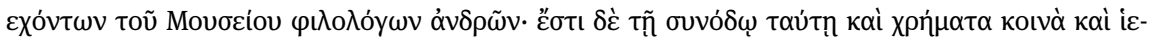

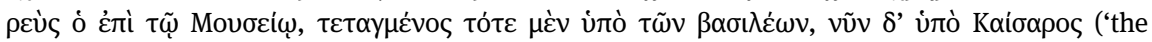
Museion has a covered walk, a lecturing hall, and a big house in which the common room of the philologist members of the Museion is found. In this society, money is held in common and there is a priest for the Museion, back then designated by the Pharaoh, now by the Roman Emperor'; Geographica XVII.1.8, ed. Radt, vol. 4, p. 428).

47 On Syrian learning and Nisibis, see Becker (2006). The seminal work on this school is Vööbus (1965). But the interests of the Nisibis scholars were apparently exclusively theological.

48 Fögen (2016) studies his approaches to language and the human sciences. 
influence of Augustine's approach to learning (see §2 above) is palpable in this quotation (Institutiones I.28.3, ed. Mynors, p. 70): ${ }^{49}$

Verumtamen nec illud Patres sanctissimi decreverunt, ut saecularium litterarum studia respuantur, quia non exinde minimum ad sacras Scripturas intellegendas sensus noster instruitur; [...] quanti enim philosophi haec solummodo lectitantes ad fontem sapientiae non venerunt, et vero lumine privati ignorantiae caecitate demersi sunt! quoniam, sicut a quodam dictum est, numquam potest plenissime investigari, quod non per viam suam quaeritur.

'However, the most holy Fathers did not decree that secular studies be rejected, for out of them our understanding of the Holy Scriptures is furthered not little. [...] But how many philosophers who eagerly read them exclusively failed to reach the fount of wisdom and were deprived of the true Light and sunk into the blindness of ignorance? For, as someone [Aristotle?] has said, something can never be fully investigated if it is not done according to its own method.'

So, although the final method and path (via) to wisdom are only reached within Christianity, secular studies are nonetheless of great propaedeutic value. With a few exceptions, they were to retain this status until the twelfth century.

\section{Latin neo-Platonism}

\$3 The influence of Greek neo-Platonism beyond what the Fathers had imported into Christianity is especially conspicuous in the following authors whose works have survived. Although an orator by profession, Marius Victorinus (ca. 285ca. 365$)^{50}$ used a strikingly unrhetorical language that aims most strongly at precision. It would seem that he learned such a precise, matter-of-fact scientific style from Plotinus ${ }^{51}$ (and other Greek authors) he translated. Unfortunately, his Plotinus translations did not reach the Middle Ages, and the Latin West had to wait until Ficino translated the Enneads into Latin again in the fifteenth century. Victori-

49 Indeed, the subsequent paragraph quotes De doctrina christiana II.61(62), ed. Green, pp. 7677.

50 On Marius Victorinus, see Hadot (1971).

51 Norden remarks regarding Plotinus' style that he is often careless ('Gesprächston', 'conversational tone'), but not always, for on occasion: 'Da erhebt sich dann seine Sprache, dem Gegenstand folgend, oft zu einer nur mit Platon vergleichbaren Grandiosität, so wenn er über das Schöne spricht, wenn er die Vollendung der Welt und die Güte des Schöpfers gegen die Gnostiker verteidigt, wenn er das selige Schauen an dem überhimmlischen Ort schildert, $\dot{\omega} \varsigma$ oíóv $\tau \varepsilon \tau \grave{\alpha}$

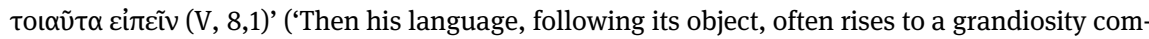
parable only to Plato's, for instance when he talks about beauty, when he defends the perfection of the world and the goodness of the Creator against the Gnostics, when he describes the blessed contemplation in the super-celestial place, "as far as it is possible to say such things" (V.8.1)'; 1958: 1:400). 
nus also translated some works by Aristotle, but his translations were largely superseded by Boethius (see $\S 6$ below), who used a similarly precise Latin style that was to become the seedbed for scholastic Latin. Von Albrecht praises Victorinus as follows: 'Mit ihm erreicht die lateinische Sprache jene Exaktheit, die ihr in philosophischen Dingen lange fehlte' ('With him, the Latin language reaches that exactness which it had long lacked in philosophical matters'; 1992-1994: 2:1284) On the other hand, this precise, terse style was perceived as obscure by Jerome (De viris illustribus 101, ed. Richardson \& von Gebhardt, p. 48):

Victorinus, natione Afer, Romae sub Constantio principe rhetoricam docuit et in extrema senectute Christi se tradens fidei scripsit Adversus Arium libros more dialectico valde obscuros, qui nisi ab eruditis non intelliguntur, et commentarios In apostolum.

'Victorinus by origin an African, taught rhetoric in Rome in the time of Constantius [II]. In extreme age converted to the Christian faith, he wrote very obscure books against Arius in a dialectical style which can only be understood by the erudite, and Pauline commentaries.'

Augustine tells us that he read some of Victorinus' translations. ${ }^{52}$ The latter's $D e$ definitionibus considers what can pass as a definition: he describes fifteen different types, but the list is not intended as exhaustive (De definitionibus 29, ed. Pronay, p. 79):

Sunt et aliae fortasse species definitionum; verum si quis invenerit, adiciat numerum.

'There may also be further kinds of definitions; in fact, if someone finds one, let him add it.'

This openness may be seen as scientific, although it must be said that except for the first (definition by something's essence) these kinds of definitions would hardly have been acceptable as more than first attempts for, say, Aristotle. Hadot (1971: 163) believed that Victorinus followed a lost Greek treatise, as the names of the kinds of definitions are all Greek. Such a treatise, if it did exist, will hardly have been by Porphyrius (Pronay, edition, p. 21), contrary to what Hadot had believed possible. A sample from De definitionibus (17, ed. Pronay, p. 67) will illustrate his language:

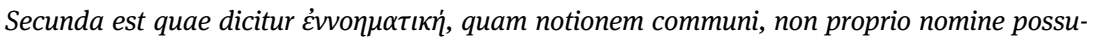
mus dicere. In omnibus enim reliquis definitionibus notio rei profertur, non substantialis explicatio declaratur, verum haec quae secunda est hoc modo semper efficitur, cum, proposito eo quod definiendum est neque dicto eius genere, verbis in rei sensum ducentibus audientem quid illud sit de quo quaeritur explicatur.

52 Confessiones VIII.3, ed. Verheijen, pp. 114-115. 


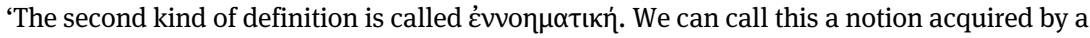
general not proper name. In all other [except the first, treated prior to the quotation] definitions a notion of a thing is mentioned, not an explanation of its essence given. In fact, this second kind is always constructed in this way, as explaining what the definiens that is sought is, after proposing what it is, but without mentioning its genus [which is what the first kind of defining does], with words that lead the interlocutor to the meaning of the thing to be defined.'
\end{abstract}

This precise but complicated style looks like a cross between Cicero and the later university scholastics. In fact, besides Greek authors, Marius quotes Cicero often and with praising adjectives, in De definitionibus especially the Topica and De inventione. The innovative terminology in Marius Victorinus includes terms such as exsistentia, essentialis, consubstantialis, praeprincipium, praeviventia. Springhetti, who lists these and other examples, concludes (Latinitas fontium, p. 28):

Merito igitur Victorinus, utpote initiator propriae terminologiae philosophicae latinae, inter 'Medii Aevi conditores' adscribendus est.

'Thus Victorinus is rightly counted among the "founders of the Middle Ages" inasmuch as he is the initiator of proper philosophical terminology in Latin.'

Hardly anything is known about Calcidius, who may have written in fourthcentury Hispania. He translated Plato's only work on natural philosophy, the Timaeus, and included a Greek-style, scientific commentary on it, which focuses on mathematics and astronomy. His vocabulary is equally innovative, for example conceptim, intermanare, silva, noys. ${ }^{53}$ Sometimes he can be observed consciously trying to map Greek terms onto Latin (ed. Waszink, p. 251):

Idem aiunt uidere nos uel tuitione, quam phasin uocant, uel intuitione, quam emphasin appellant, uel detuitione, quam paraphasin nominant.

'[The geometers] say that we see either by direct vision, called $\varphi$ ó reflected vision, called है $\mu \varphi \alpha \sigma ı \varsigma$ [reflection] in Greek, or opaquely translucent vision, called $\pi \alpha \rho \alpha \dot{\varphi} \alpha \sigma \iota \varsigma$ [?]. ${ }^{54}$

Thus, corresponding Latin prefixes are used to duplicate Greek terminology from optics. The translations are based on tueor $=\varphi$ iivo $\mu \alpha$. In this case, the new Latin

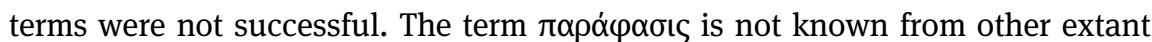
sources on optics. This text was to become very influential among twelfth-century Platonists in particular.

53 See Dronke (2008: 8-12).

54 My glosses of the Greek words follow the explanations by Calcidius right after this excerpt. 
A further important neo-Platonist Latin author was Ambrosius Theodosius Macrobius (fl. ca. 400), who wrote a commentary on Cicero's Somnium Scipionis (thereby preserving this lost part of Cicero's De re publica). The commentary stands in the tradition of advanced Greek scientific commentaries and was influential in the Middle Ages. ${ }^{55}$ These authors, together with Martianus (§5) and Boethius (§6), provided the twelfth-century Platonists with their best sources of information about Greek Platonism.

\section{The study of Latin}

\$4 Toward the end of Antiquity, there are a surprising number of surviving Latin grammatical texts. ${ }^{56}$ Most of them are clearly intended for school use, and are not meant as scientific studies of language. Usually, very little about the authors is known, and they tend to copy much from one another. Ultimately, their grammatical approach goes back to Hellenistic Greek grammar, which had been framed by the Stoics as a descriptive science. ${ }^{57}$ In Late Antiquity, grammar becomes part of school teaching and petrified as a dogmatic structure, losing its research nature. The grammarians Aelius Donatus (fl. ca. 350) and Priscian (fl. ca. 500) are the two most influential ones for the centuries to come. We take a brief look at the former here. Little is known about him, apart from the fact that, apparently, he was Jerome's teacher ${ }^{58}$ and thus flourished in the middle of the fourth century. He wrote an Ars maior and an Ars minor for beginners. His more advanced grammar is very systematic, though still at a rather elementary level and not at all original. Grammatical categories are named, sometimes defined, subcategories are introduced, and usually examples are given. But the content is not treated organically, and no unclear points are discussed: the work resembles more a list of things to be learned by pupils or an inventory. ${ }^{59}$ As an example, consider Ars maior II.1, ed. Holtz, p. 613: ${ }^{60}$

55 See Schedler (1916); see also the edition of Macrobius by Armisen-Marchetti.

56 See the online collection Corpus Grammaticorum Latinorum (http://kaali.linguist.jussieu.fr/ CGL/index.jsp) by Alessandro Garcea, which includes over one hundred texts. They can also be searched on Corpus Corporum.

57 See Holtz (Donatus edition, pp. 3-11).

58 Jerome, Contra Rufinum I.16, ed. Lardet, p. 46.

59 More details on the work's form can be found in the edition by Holtz, pp. 49-52. See Leonhardt (2013: 97) on the importance of Donatus.

60 The canon of these eight parts of speech has lived on with few changes until recently. The main change in what has become the standard system is that adjectives take the place of participles. Practically the same system will be used in our corpus studies below (chap. 18). 
partes orationis sunt octo, nomen, pronomen, uerbum, aduerbium, participium, coniunctio, praepositio, interiectio. ex his duae sunt principales partes orationis, nomen et uerbum. Latini articulum non adnumerant, Graeci interiectionem. multi plures, multi pauciores partes orationis putant. uerum ex omnibus tres sunt, quae sex casibus inflectuntur, nomen, pronomen et participium.

'There are eight parts of speech: noun, pronoun, verb, adverb, participle, conjunction, preposition, interjection. Among these, two are the main parts of speech: noun and verb. The Latins do not count the article, the Greeks the interjection. Many posit more, many fewer parts of speech. There are three of them that are inflected, in six cases: noun, pronoun, and participle.'

Holtz (edition, p. 56, quoting Fuhrmann 1960) shows that this kind of technical inventory style is a development of fourth-century-BC Hellenism. Greek technical vocabulary had long since been translated into and adapted to Latin, and was in many cases to remain in use into the present day. Similar dispositions of facts and a similar unrhetorical style are encountered in many of the following manuals.

\$5 In this 'age of résumés', the one that had the greatest impact on the Middle Ages was written by Martianus Capella, most likely between 410 and 439, in an allegorical, neo-Platonist coating: the prosimetrum De nuptiis Philologiae et Mercurii. It introduced the Seven Arts to mediaeval readers; the work began to be used as a schoolbook in Carolingian times and became very popular. His difficult and often obscure style led to several Carolingian commentaries, as well as to a philological reworking of the text, as can be seen from the existence of a Carolingian vulgate text that introduced many conjectures, some of them still retained in modern critical editions. ${ }^{61}$ Stahl (1971: 1:30) is certainly right when he claims 'it would be hard to find a Latin author with a more unusual vocabulary'. He differentiates two groups of neologisms: bold compounds and technical or scholarly words (often Greek). One can get an impression of this from a list of Georges entries attested only for Martianus. They number nearly two hundred (excluding proper names and epithets of divinities); a-d are listed here:

abdicative; adiaculatus; adoperte; aequicrurius; agalma; aggarrio; agoge; anacamptos; animator, -oris; antemeridialis; antipodus; antisagoge; arhythmos; asomatus; assecutor, -oris; assertum; astrifico; astriloquus; asynthetus; autumnasco; balteo; blandificus; bupaes; calym$\underline{\text { ma; }}$; carians; cernentia; collema; colorabilis; compositivus; concussus; conexe; conspicabundus; contigue; conubialiter; culmino; cunctalis; cuncticinus; curvatio; declarative; decretio;

61 On the complicated textual tradition, see Shanzer (1986), and Guillaumin in the introduction of his edition of book IX. 
dedicative; deluctatio; demerso; dendrites; desorbeo; diastematicus; dilophos; directilineus; discussius; disemus; disgregus; diversicolor, -oris; dulcinervis; dysprophoron. ${ }^{62}$

As usual, it is impossible to guess how much of this was really coined by Martianus and how much was already in circulation but does not happen to be found in the surviving sources. Some of the words are merely Greek in Latin letters (underlined, in total 46 of 186), some are attempts to imitate Greek (such as colorabilis for $\chi \rho \omega \mu \alpha \tau$ «ó $),{ }^{63}$ but most are Latin suffix constructions and compounds, as Martianus himself states in the next quotation. In general, Martianus is hardly less afraid to coin new terms than the most extreme Greek authors, such as Democritus; for instance, he uses some rather daring compounds in order to name cli-

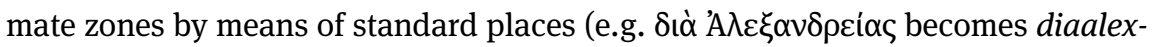
andrias). Martianus is conscious of the process of linguistic innovation (De nuptiis Philologiae et Mercurii V, §510, ed. Willis, p. 176):

\begin{abstract}
quod si qua res propria verba non habeat, novanda sunt aut alienis utendum. novantur autem duobus modis verba: aut quadam fictione aut declinatione praesumpta, aut duorum, quae usitata sint, coniunctione composita. finguntur maxime cum transferimus, ut qui poeotetas 'qualitates' esse dixerunt, quod nomen numquam fuerat in Latinis. ¿in quo et auribus temperandum et insolentia fugienda. quam vitans Cicero soterem 'salvatorem' noluit nominare et ait 'qui salutem dedit'; illud enim nimis insolens videbatur.

'That if some thing does not have its own designation, words have to be created or words from other areas have to be used. They can be created in two ways: either taken up through invention or derivation, or compounded by juxtaposition of two current ones. They are most

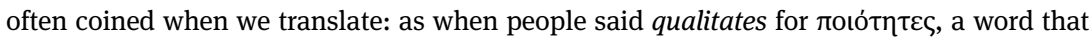
had not existed in Latin. When doing this, one should be temperate with the ears [of listeners] and shun extravagance. Avoiding which, Cicero did not want to call $\sigma \omega \tau \eta \dot{\rho}$ salvator and said qui salutem dedit, the former seeming too extravagant to him.'
\end{abstract}

Martianus’ open linguistic approach becomes even clearer in IV, §379, ed. Ferré, p. 30, where he states that one should not be afraid to complete missing paradigms: if one can say pinna ('wing') and pinnatus ('winged'), why not derive a word from pes ('foot') meaning 'footed'?64 Martianus' novel language, though similar to Tertullian's in boldly using obscure or new terminology, is yet of a somewhat different kind. Much of the text's considerable difficulty lies in his often very

62 Compare this list with Stahl's study of this topic in an appendix (1971: 250-252).

63 Martianus apologises for the word in the usual manner with chromatice, quam nos vix forsan recte colorabilem memoramus (' $\chi \rho \omega \mu \alpha \tau \iota \kappa \eta '$, which we perhaps hardly correctly mention as colorabilis'; IX, §942, ed. Guillaumin, p. 41).

64 Compare chap. $12 \S 5$ below on Raimundus Lullus, who will go very far in this direction. 
artificial and deliberately ambiguous syntax. ${ }^{65}$ Martianus certainly knew Apuleius, ${ }^{66}$ and seems to try to imitate him and to exaggerate his non-classical tendencies even more.

Martianus occasionally insinuates that the scientific studies he describes in his work are more apt to the Greek, for example when Geometria says: Romuleis ut potero uocibus intimabo ('I will say it in Roman words as far as I can'; VI, §587, ed. Ferré, p. 8). He sees the mathematical sciences in particular as Greek and hard to express in Latin. As he indeed often uses Greek terms, this does not seem to be a mere topos for him. He invokes Athena as follows (VI, §574, ed. Ferré, p. 3):
O sacra doctarum prudentia fontigenarum,
sola novem complens, Musis mens omnibus una,
deprecor: ad proprium dignata illabere munus
inspirans nobis Graias Latiariter artes.
' $O$ sacred wisdom of the learnèd Muses born at the fountain, thou alone makest up the nine, one mind to them all, thee I beseech, deign to bestow thy proper gift, inspiring us to teach the Greek arts in a Latinate manner.'

In passing, he seems to allude to a scientific method applicable 'to all arts', formulated for astronomers (III, §230, ed. Willis, p. 62):

[...] et astronomus quaedam facit, ut per ea cognoscat, quae debeat comprobare.

'[...] as the astronomer does certain things in order to understand with the help of them what he has to prove.

Nevertheless, it would seem that Martianus misunderstood quite a few of the more difficult technical details, especially in the quadrivium, ${ }^{67}$ but in some fields,

65 This special style was abhorred by Ciceronian classicist scholars. Schanz \& Hosius call it 'widerlich' ('revolting') and remark that 'die Geschmacklosigkeit durchdringt das ganze Werk' ('bad taste permeates the entire work'; 1922-1935: 4.2:168). Lemoine (1972) tried to evaluate Martianus' style without Ciceronian prejudice. It would seem to me that Martianus' style does have its own kind of considerable beauty and elegance.

66 There are quite a few words known only from these two authors in Antiquity (according to Georges), such as infinibilis ('infinite'), capillitium ('hair'), colliculus ('little hill'), declarativus ('explanatory'), nuptu(r)ire ('to wish to marry'), pluriformis ('of many shapes'), praediatus ('wealthy'), reflexim ('conversely'), susurramen ('murmur'), ultramundanus ('beyond the world'), undanter ('in a waving manner').

67 Instances can be found in Stahl's detailed commentary (Stahl \& Johnson 1971). For example, in VI, §§597-598, Martianus does not understand Eratosthenes' measurement of the Earth's circumference, but according to Stahl no Latin writer in Antiquity did. VIII, §876 claims that the summer tropic passes though Meroe, when it actually passes through Syene; and in VII, §756 Martianus seems to fall short in basic arithmetic. 
such as harmonics and metrics, ${ }^{68}$ he does seem to be at the height of what was then possible.

\$6 As the knowledge of Greek was disappearing toward the end of the Western Roman Empire, ${ }^{69}$ more translations are made, but few of them have come down to us (or even the Middle Ages). An exception to this dearth of Greek thought in the Middle Ages is theology (including Church history). Many important Greek Church Fathers were translated, especially by Rufinus of Aquileia, who translated works by Basilius, Origen, Gregory of Nazianzus, Eusebius, and Pamphilus. ${ }^{70}$ But the more theoretical Greek sciences were still hardly translated at all; the translations by Anicius Manlius Severinus Boethius (ca. 480-524), especially of Aristotelian works, are the one great exception, with far-reaching consequences. ${ }^{71} \mathrm{He}$ was to be praised as maximus latinorum philosophorum ('the greatest of the Latin philosophers'). ${ }^{72}$ He had realised that it was necessary to save as much Greek knowledge as possible by transplanting it into the Latin language. Although real reading knowledge of Greek was indeed to remain very rare in the Latin Middle Ages (until the Italian Renaissance in the fifteenth century), Greek culture and its language always remained prestigious; in fact, many authors used 'ornamental Greek' - some Greek words here and there to playfully adorn their texts, possibly also to show off their erudition. ${ }^{73}$

Boethius' translations of the Aristotelian Organon (except of the Analytica posteriora), together with commentaries, were to become the basic texts for learning logic throughout the Middle Ages, later known as the logica vetus. Besides this, his works on the quadrivium were equally influential, especially De arithmetica and De musica; his treatises on geometry and astronomy have been lost but did enjoy some influence. ${ }^{74}$ Boethius also mentions a work he apparently wrote

68 Maritianus also wrote a brief work on metre that has recently been rediscovered. A provisional edition can be read in Guillaumin (2008). The text was discovered by de Nonno (1990), who promised but failed to deliver an edition.

69 On Greek in the Latin Middle Ages, see Bischoff (1951), then Berschin (1980).

70 On Rufinus, see Murphy (1945); on his translation style, see Marti (1974: 91-92).

71 We encountered Calcidius' translation of the Timaeus above, and medical works were also translated, e.g. Dioscurides' De materia medica in the sixth century.

72 Abelard, Theologia christiana I.134, ed. Buytaert, p. 129, calls him thus, although he also uses this epithet for Cicero (Introductio ad theologiam PL 178.1087C).

73 This very fitting term, ornamentales Griechisch, was proposed by Berschin; on this topic, see Stotz (2011). It is contrasted to 'terminological Greek' (borrowings with a scientific or liturgical function). The most avid users of ornamental Greek in the Early Middle Ages were the Irish.

74 See Gruber (2011: 24-25), with references. 
on physics, but nothing further is known about it. ${ }^{75}$ His De arithmetica (mostly a translation of Nicomachus of Gerasa) was to become the basic text on the subject in the Middle Ages. It states (I.1, ed. Oosthout \& Schilling, p. 9):

Est enim sapientia rerum, quae sunt suique immutabilem substantiam sortiuntur, comprehensio ueritatis.

'For wisdom is the truthful understanding of the things that exist and that have their own unchanging substance.'

Here Boethius is using sapientia for 'science'. ${ }^{76}$ In his theological works, Boethius stresses the importance of ratio alongside auctoritas; indeed, he hardly cites authorities and makes very broad use of reasoning. For his approach to theology and his emphasis of logic Boethius is often rightly considered the father of scholasticism (or the 'last Roman and first scholastic'; Grabmann 1957: 1:148), although his methodology was not to find much imitation until half a millennium later. He decided that the ideal of a most faithful translator (fidus interpres) ${ }^{77}$ should be adopted for scientific works when translating from Greek. This resulted in a verbum de verbo translation, ${ }^{78}$ a kind of Greek in Latin words, as we have already encountered above in Jerome's Vulgate. Boethius puts this very similarly (In Porphyrium I.1, ed. Brandt, p. 135): ${ }^{79}$

vereor ne subierim fidi interpretis culpam, cum verbum verbo expressum comparatumque reddiderim. Cuius incepti ratio est quod in his scriptis in quibus rerum cognitio quaeritur, non luculentae orationis lepos, sed incorrupta veritas exprimenda est.

'I fear I will suffer the blame of the faithful translator because I render each word by one and the same word. The reason for this undertaking is that in writings in which knowledge of things is sought, not the beauty of distinguished oratory but the uncorrupted truth is to be expressed.'

75 Boethius, In librum De interpretatione Aristotelis maior III.9, ed. Meiser, p. 190: sed quoniam tres supra modos proposuimus contingentis, de quibus melius in physicis tractavimus, singulorum subdamus exempla ('but as we have above proposed three modes of contingency, which we treated better in De physicis, we shall provide examples for each').

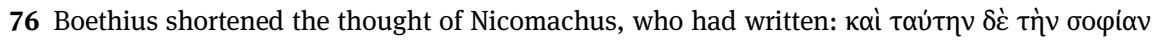

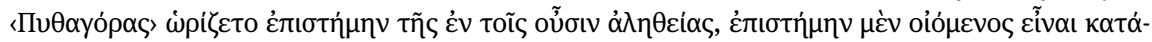

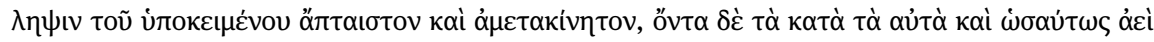

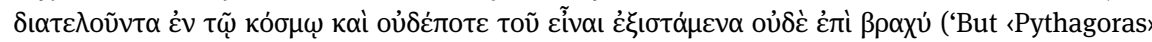
defined wisdom as knowledge/science of the truth in what is, conceiving "science" as the infallible and unchangeable apprehension of the underlying being, and "what is" to be what persists always uniformly and the same way in the world and that never departs from being, not even for a brief moment'; Introductio arithmetica I.1.2, ed. Hoche, p. 2).

77 See further Ebbesen (2009: 38-42); Schwarz (1985); Marti (1974: 87-89).

78 On this technique, see Marti (1974: 64-81).

79 On his translation style, see Vogel (2016: 131-144). 


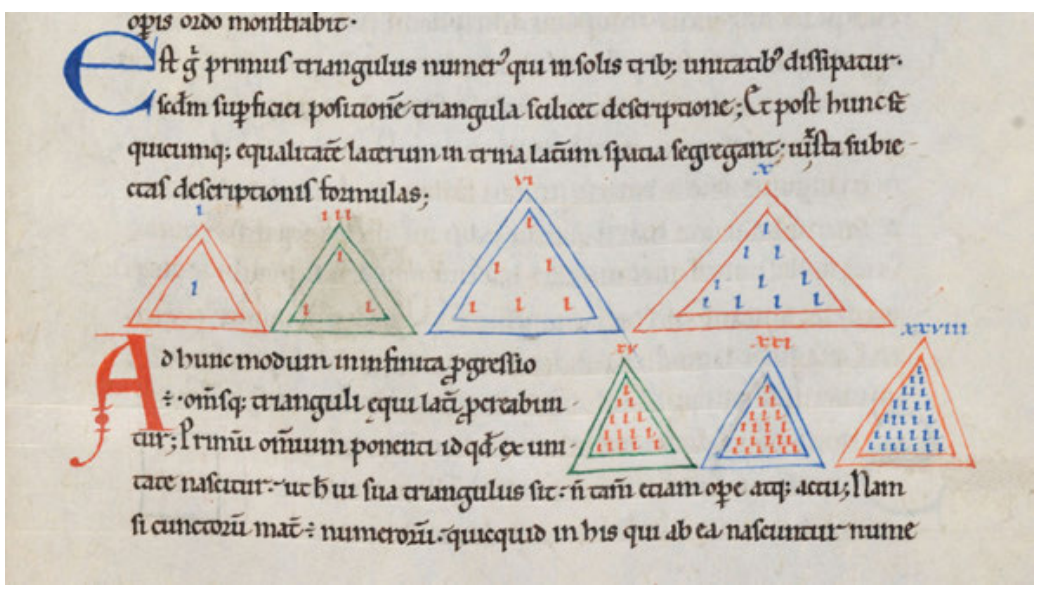

Fig. 14: A diagram explaining triangular numbers from Boethius, De arithmetica II.7. In modern notation they equal $n(n+1) / 2$ for $n \in \mathbb{N}=1,3,6,10,15,21,28$, etc. St. Gallen, Kantonsbibliothek, Vadianische Sammlung 296, fol. 26r. Reproduced with permission.

Source: https://www.e-codices.unifr.ch/en/list/one/vad/0296.

Obviously, Boethius was an author capable of using very different styles for different purposes: his scientific writings are stylistically very different from his brilliant Consolatio philosophiae, which also includes some remarkable poetry. At the other end of the spectrum, Boethius wrote two commentaries on Porphyry's Isagoge. This introductory text also became part of the mediaeval logica vetus and was much read, albeit mostly in the guise of Boethius' translation alone, without the commentaries. Thirty-four and twenty-one manuscripts are known of two commentaries respectively (Gruber 2011: 31). In contrast to the shorter first commentary, which is a didactic dialogue in the Ciceronian tradition, the second, in 'wissenschaftlich-technische Fachsprache' (Gruber 2011: 30-31), is meant for more advanced readers. Content-wise, Brandt concludes that the two commentaries differ little. ${ }^{80}$ Whereas the first commentary used the translation by Marius Victorinus (lost, except in the commentary), Boethius made a fresh, very verbatim one for the second commentary. He himself puts it thus (In Porphyrium II.1.7, ed. Brandt, p. 154):

ut in prima editione dictum est, hanc expositionem nostro reseruasse iudicio, ut ad intellegentiam simplicem huius libri editio prima sufficiat, ad interiorem uero speculationem confirmatis paene iam scientia nec in singulis uocabulis rerum haerentibus haec posterior colloquatur.

80 Sed uere discrepare inter se duos commentarios non repperi ('But I did not find the two commentaries to differ substantially'; edition, p. xxi). 
'as was announced in the first commentary, this exposition was kept back by our judgement so that for a simple understanding the first commentary on this book suffices, but for deeper thinking on the part of those who are already advanced in this science and do not stumble on single words, these following matters will be discussed.'

A comparison of a random passage in the two commentaries is given below, com-

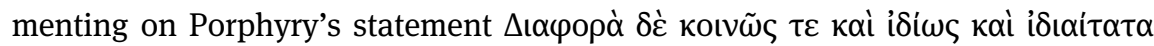
$\lambda \varepsilon y \varepsilon \dot{\sigma} \sigma \omega \omega$ ('Difference is said in a common, in a special, and in a most special way'; Isagoge, ed. Busse, p. 8). Page numbers from Brandt's edition are given in parentheses; Brandt marks translated text with Sperrdruck.

\section{Editio prima}

(85) Hic Fabius: Uberrime. inquit, a te hesternis uigiliis de generibus et speciebus expositum est. sed, ut dici audio, subtilior de differentiis tenuiorque tractatus est. - Non. inquam, inmerito. nam uarie acceptae differentiae uarias habebunt etiam potestates. erunt namque alias genera, alias species, alias uero differentiae. sed hoc postea demonstrabitur, nunc uero ita, ut arbitror, textus est: Omnis differentia et communiter et proprie et magis proprie dicitur. Differentiam quoque multis modis appellari designat. dicit autem tribus his modis fieri differentiam, cum aut communes sunt aut propriae aut magis propriae. communes sunt quibus omnes aut ab aliis differimus aut a nobis ipsis. nam sedere uel ambulare uel stare differentia est; nam si tu ambules, ego uero sedeam, in situ ipso atque ambulatione differimus. et item ego cum nunc sedeo, postea uero si ambulem, communi a me ipso differentia discrepabo. propriae uero sunt (86) quae unius cuiusque indiuidui

\section{Editio secunda}

Differentia uero communiter et proprie et magis (240) proprie dicitur. [...]

Tribus modis aliud ab alio distare praediximus, genere, specie, numero, in quibus omnibus aut secundum substantiales quasdam differentias alia res distat ab alia aut secundum accidentes. nam quae genere uel specie distant, substantialibus quibusdam differentiis disgregata sunt, idcirco quoniam genera et species quibusdam differentiis informantur. nam quod homo ab arbore genere distat, animalis sensibilis qualitas in eo differentiam facit. addita enim sensibilis qualitas (241) animato animal facit, eidem detracta facit animatum atque insensibile, quod uirgulta sunt. igitur homo atque arbor genere differunt utraque enim sub animalis genere poni non possunt -, differentia sensibili secundum genus discrepant, quae unius ex propositis tantum genus, id est hominis informat, ut dictum est. illa uero quae specie distant manifestum est quod ipsa quoque differentiis 
formam aliqua naturali proprietate depingunt, ut si quis sit caecis oculis uel crispo capillo; etenim propria unius cuiusque singuli hominis sunt quoquo modo ista nascuntur. substantialibus discrepant, ut homo atque equus differentiis substantialibus discrepant, rationabilitate atque inrationabilitate. ea uero quae indiuidua sunt et solo numero discrepant, solis accidentibus distant.

The dialogue form of the first commentary accounts for some obvious differences: the style is more personal, less 'abstract'. But the second commentary also clearly uses a more specific terminology: accidentes, sensibilis qualitas, informat. The second commentary is longer ( 37,000 vs 26,000 words), but the vocabulary also seems to be somewhat richer. ${ }^{81}$ The words that are only found in the second commentary include technical terms like adventicius, absolutus, accidentalis, adaequatio, alteritas. Gruber (2011: 31) further observes what he calls typically scholastic syntax (like dico quoniam) and vocabulary (specificus, subiectum, praedicatum). This second commentary can be seen as the ancestor of scholastic Latin (see chap. 11). ${ }^{82}$ Much new Latin vocabulary goes back to Boethius, especially in logical Aristotelian terminology, ${ }^{83}$ and was to remain very stable throughout the lifespan of Latin.

It is interesting to note in passing that Sergius of Rēšainā (d. 536) fulfilled a very similar rôle in salvaging Greek logic for the Syriac language to what Boethius did for Latin. ${ }^{84} \mathrm{He}$ also translated the Organon and Porphyry's Isagoge. It would in general be interesting to compare the appropriation of Greek science in Latin and Syriac/Arabic.

\$7 Visigothic Hispania enjoyed a Nachblüte of Roman culture in the sixth and seventh centuries. In this flourishing post-Roman culture, important scholarly texts were written on history, grammar, and law (such as the Lex Visigothorum, ca. 654), as well as encyclopaedias. ${ }^{85}$ Latin culture eventually came to an abrupt halt through the Muslim invasion of the Iberian peninsula (beginning in 711); after this, Arabic culture was to flourish here, possibly more than anywhere else in the

81 1,003 lemmata are used in both commentaries (according to Corpus Corporum), in total somewhat more in the second $(1,836 ; 1,693$ if shortened to the length of the first commentary) than in the first $(1,608)$.

82 See Smith (1925).

83 Gruber (2011: 101); Roelli (2014a: 950-954).

84 See Hugonnard-Roche (2004).

85 There is a list of the writers in this Nachblüte in Díaz y Díaz, Index scriptorum latinorum medii aevi hispanorum. 
ensuing centuries, but to the detriment of Latin culture. We shall take a brief look at the most important encyclopaedist of the Middle Ages here: Isid ore of Seville (ca. 560-636). Especially his Etymologiae were immensely successful; more than a thousand manuscripts are known. ${ }^{86}$ The study of his sources is by far not complete, but it is clear that Isidore used material from many authors, probably often through florilegia, much more often pagan than Christian ones. ${ }^{87}$ Similarly to Varro in his De lingua latina, but on a much grander scale and organised into scientific fields, Isidore treats the semantic, 'etymological' webs of things. His twenty books treat the following subjects (see Díaz y Díaz, in the Oroz Reta \& Marcos Casquero edition, p. 174):

- book I: grammatica - linguistics, grammar,

- book II: rhetorica et dialectica - oratory and logic,

- book III: mathematica - the quadrivium,

- book IV: medicina - medicine,

- book V: leges et tempora - jurisprudence and a world chronology,

- books VI-VIII: theology,

- book IX: linguae, gentes, regna, etc. - history and human geography,

- book X: vocabula - an alphabetical list of words and their webs of meaning (etymologiae),

- book XI-XII: homo, animalia - biology,

- books XIII-XIV: mundus, terra - physical geography,

- book XV: engineering,

- book XVI: lapides et metalla - studying solid bodies,

- book XVII: agriculture,

- book XVIII: war tactics,

- books XIX-XX: household tools.

This covers much more than the Liberal Arts (covered in books I-III) and, indeed, even more than 'science' as defined above; the last few books, in particular, seem to move toward a general treatment of human culture. ${ }^{88}$ Of course, Isidore knows the Seven Arts (I.2, ed. Lindsay), but he also knows other classifications of philosophy, such as that into ethica, physica, and logica (II.24.3, ed. Marshall, p. 103). Samples of Isidore's clear and rather plain Latin have already been quoted above

86 Díaz y Díaz, in the Oroz Reta \& Marcos Casquero edition, p. 200, quoting Anspach (1966).

87 On the sources, see Díaz y Díaz, in the Oroz Reta \& Marcos Casquero edition, pp. 189-200. On the work, its genesis, and importance, see Fontaine (2000).

88 Admittedly, however, the first half of the work (containing the artes) is more commonly found in the manuscripts (see Beeson 1913: 83). This long work was often transmitted in two volumes, and these not always together. 
(chap. $2 \S 4$, chap. $3 \S \S 3,8$ ). As he himself puts it while speaking about rhetoric (Etymologiae II.16.1-2, ed. Marshall, p. 65):

Latine autem et perspicue loquendum. Latine autem loquitur, qui uerba rerum uera et naturalia persequitur, nec a sermone atque cultu praesentis temporis discrepat. Huic non sit satis uidere quid dicat, nisi id quoque aperte et suauiter dicere; ne id quidem tantum, nisi id quod dicat et facere.

'One has to speak in Latin [as distinct from the vernacular lingua rustica] and in a clear manner. Someone speaks Latin if he sticks to the words for things that are genuine and natural, does not depart from the way of speaking and the practice of his time. For him, it is not enough to see what to say, he must also say it clearly and gracefully; and not only this, but he must also practise what he speaks about.'

Despite this, Isidore uses quite a lot of unusual Latin words, but in stark contrast to writers such as Apuleius, Tertullian, or Martianus Capella, in his case these words are nearly always names for realia that he explains. Some examples: ${ }^{89}$

Genera lacertorum plura, ut botrax, salamandra, saura, stellio.

'The kinds of reptiles, such as botrax, salamander, lizards, newts.'

Among these, botrax is not otherwise known and may be a vulgar form of

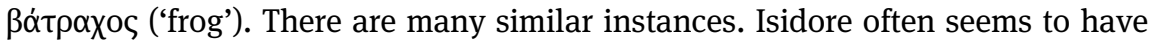
drawn on colloquial sources. Such unusual words are mostly nouns, but not only: XIX.28.8 (ed. Rodríguez-Pantoja, p. 239) knows a colour blabus ('blue’?) and another mesticium ('mixed'?). ${ }^{90}$ More examples will be examined below (chap. 21 §3), such as sarna, which seems to be an autochthonous Hispanic term for the disease impetigo.

Isidore's differentiation between ars and disciplina/scientia was to remain common ground for the times that followed (Etymologiae I.1.3, ed. Lindsay, quoted in Latin in chap. $3 \S 3$ above):

Between ars and disciplina Plato and Aristotle would posit the distinction that ars is about things that can also be different, but disciplina is about things that cannot turn out differently. So, when something is studied using true arguments it will be a disciplina, when it is treated in a manner [only] resembling truth and open to opinion, it will have the name ars.

Now, after what has been said above (chap. 7 §5), this statement is at least a considerable simplification. Aristotle was aware that غ̇лıбт́ $\mu \eta$ (disciplina) should not only cover events that cannot turn out differently, but should also cover those that happen only for the most part. If one uses Isidore's strict division, only the fields

89 From Etymologiae XII.4.34, ed. André, p. 161. See Sofer (1930: 103).

90 See Sofer (1930: 108). 
of the quadrivium will remain disciplinae; most of the topics of his Etymologiae will then be artes. As has been mentioned ( $\$ 5)$, this point of view fits Platonism well, but not Aristotle's attempt to explain perishable things scientifically as well. The fact that his authorities contain contradictions was apparently not seen as a major problem by Isidore. He often just reports contradicting authorities one after the other. As Fontaine puts it (1959-1983: 2:775): ${ }^{91}$

Cette pure et simple juxtaposition des sources, qui admet souvent sans discussion la contradiction entre les fragments assemblés, représente le niveau le plus élémentaire de la compilation 'doxographique', celle que les théologiens grecs contemporains d'Isidore utilisent dans leur $\sigma \varepsilon \tilde{\rho} \rho \mathbf{\imath}$ [sic]. [...] A l'image d'un monde réduit à un assemblage d'essence particulière, l'encyclopédie isidorienne s'accommode souvent de cette simple juxtaposition d'extraits.

'This pure and simple juxtaposition of sources, which often admits without discussion the contradiction between the assembled fragments, represents the most elementary level of "doxographic" compilation, the one used by contemporary Greek theologians, contemporaries of Isidore in their catenae [...]. Like a world reduced to an assemblage of particular items, Isidore's encyclopaedia is often content with this simple juxtaposition of extracts.'

\section{Science in the Early Middle Ages?}

\$8 The Middle Ages are usually considered to begin after Cassiodorus and Isidore in Latin literary studies (thus often allowing a longer time span for the Hispanic Nachblüte). For our topic, the great caesura, however, is within the Middle Ages: before and after the twelfth century. The time before is usually divided into the Early Middle Ages or 'Dark Ages', during the warlike time of the migrations of Germanic tribes, followed by the Carolingian renovatio, which in turn slowly degenerates into the saeculum ferreum (the tenth century), and finally develops into a new cultural flowering through the eleventh century. As CISAM (Centro italiano di studi sull'alto medioevo) held a major conference on science in this epoch in 2019, a few words will suffice here; the interested reader is referred to the rich proceedings of this conference. ${ }^{92}$

For the present topic, in fact, there is little difference between Late Antiquity and the Early Middle Ages: Latin science remains mostly compendium and school erudition, the main method is study based on antique authorities, and first-hand research, especially in the natural sciences, remains rare. The science of the Early

91 In contrast, harmonising contradicting authorities will become the major preoccupation of the scholastic method (see chap. 11).

92 See, among others, Roelli (2020a) in the proceedings; other contributions give examples of sciences that were seriously studied in this epoch. 
Middle Ages is a topic that has for long been neglected. In the past, it was occasionally claimed that the Latin Middle Ages were altogether devoid of scientific activities before the twelfth century. Even if science is defined from a modern point of view as a growing corpus of experimentally gained knowledge, some exceptions will be found to such a sweeping statement; if, however, the present broader approach is used, it will be seen that some sciences were still widely practised, of course within a Christian theological Denkstil - itself a product of the neo-Platonist approach, which was considered the most scientific at the time, as discussed above (\$2) and below (\$13). Despite the Middle Ages’ focus on repeating what Roman Antiquity knew about the Seven Arts, it is becoming increasingly acknowledged that several preconditions for scientific thought did originate in the Middle Ages, even in the natural sciences, but first and foremost in 'sciences' such as historiography (e.g. consistent dating of events being worked out in the widely practised computus), jurisprudence (mostly from the eleventh century onward in Bologna), or biblical studies and theology (beginning in Carolingian times). With their schooling in the Liberal Arts and these new developments, the earlier Middle Ages laid the foundation for the reassimilation of the Greek scientific spirit in the twelfth century, which, of course, remains the great watershed. ${ }^{93}$

\section{The 'Dark Ages'}

\$9 After the fall of Western Rome and during the long period of wars in Italy and Gaul, monasticism took an ever firmer hold of Latin society. ${ }^{94}$ Monasteries usually collected books following the example of Cassiodorus (\$2). In the seventh and eighth centuries, monastic libraries grew and educated teachers moved between them in order to teach the monks and younger pupils - primarily basic matters important for monastic life, such as liturgy, reading, and writing, but also Latin grammar, historiography, calendar calculation (computus), and the Liberal Arts. Nonetheless, in most places truly educated authors remain few and far between. Among the Longobards, during a steady growth of monasteries in the mode of St Benedict, one may think of the historian Paul the Deacon (ca. 720-799), or in Ireland from the seventh century onward a special interest in grammar can be registered..$^{95}$ Especially in Anglo-Saxon England, monastic erudition grew in this period and produced important writers such as Aldhelm (ca. 639-709) or 'the

93 On this development, see Fried (2001).

94 Riché (1979) is still an excellent introduction to (monastic) schools in these times; for a more recent one, see Shank (2013). The proceedings of another CISAM conference (Sestan 1972) provide a wider picture of early mediaeval schools.

95 See Cardelle de Hartmann (2019). 
Venerable' Bede (672/673-735). ${ }^{96}$ Bede wrote in a clear style and was much concerned with perspicuitas; his intentions are nearly always didactic. He wrote a lot, even taking into account that many writings circulated under his name in the later Middle Ages and the authenticity of some is still under debate. The PL contains works attributed to him comprising some two million words. Besides being a good historian, his studies of computus became fundamental for calendar calculations in the following centuries; he also wrote on geography and natural philosophy. For his Historia ecclesiastica gentis Anglorum, he consulted much archival material in England and even had copies brought to him by a collaborator from Rome. 'His histories [...] mark momentous advances in the science of historiography' (Brown 1987: 81). On the other hand, Bede cannot be said to have been much of a natural scientist, with the possible exception of his De temporum ratione. ${ }^{97}$ Indeed, his entire programme of studies was very much based on the Bible and its interpretation, and - in contrast to the young Augustine and Cassiodorus - he emphasises often that non-Christian studies are best avoided. Symptomatically, in his Commentarii in Pentateuchum III.22, PL 91.355D, commenting on Leviticus 22:25, he states:

Sed neque panis alienigenae offertur Deo, id est doctrina haereticorum, vel vana studia saecularium litterarum, quae ab Ecclesia aliena sunt. Tales hostiae repudiantur a Domino. ${ }^{98}$

'But the bread of the woman born in foreign lands shall not be offered to God; this means teachings of the heretics, or vain studies of secular letters, which are foreign to the Church. Such offerings will be rejected by the Lord.'

Nonetheless, in good Roman and Augustinian tradition, what is useful among the sciences is appropriated. His De natura rerum is a reworking of Isidore and Pliny, and is 'certainly a great improvement over Isidore's De natura' (Brown 1987: 36), but it is still a résumé of past insights, albeit one of only a few, and of a quality rare before Carolingian times. Bede's successor Egbert taught the young Alcuin, who was to become a central figure in the Carolingian renewal.

96 Brown (1987) provides a good introduction to Bede and his writings.

97 Nothaft (2012) on computus in general. As Riché puts it: 'De même, l'intérêt que les Insulaires ont pour les recherches scientifiques est dicté par des préoccupations religieuses' ('Nonetheless, the interest of the islanders in scientific research is dictated by religious concerns'). But '[a]utour de la ratio temporum, les Insulaires reconstituent un programme scientifique qui n'existait plus dans l'école antique' ('around the ratio temporum, the islanders reconstitute a scientific programme that had no longer existed in the schools of Antiquity'; 1979: 60)

98 Similarly in e.g. Allegorica expositio in Samuelem IV.10, PL 91.711A. 
\$10 Charlemagne's (742-814) intention was to return to the former Roman glory with himself as the emperor. ${ }^{99}$ After conquering the Longobardic kingdom in 774, he brought Italian scholars - Paulinus of Aquileia, Petrus of Pisa - to teach at his court. Among many other things, his ambitious renovatio was to entail educational reforms detailed in the Epistola de litteris colendis (ca. 785), probably written by Alcuin of York (ca. 735-804) after a meeting of the two in Rome, and in the much more successful Admonitio generalis (789). ${ }^{100}$ The former states what a priest should know, including the topics (ed. Boretius \& Krause, p. 121):

1. De lectionibus. 2. De cantu. 3. De scribis. 4. De notariis. 5. De diversis disciplinis. 6. De compoto. 7. De medicinali arte.

'(i) Reading, (ii) Church singing, (iii) Scribes, (iv) Clerks, (v) The various sciences, (vi) Computus, (vii) The medical art.'

In his Epistola generalis, Charlemagne states (ed. Boretius \& Krause, p. 80):

Igitur quia curae nobis est, ut nostrarum ecclesiarum ad meliora semper proficiat status, oblitteratam pene maiorum nostrorum desidia reparare vigilanti studio litterarum satagimus officinam, et ad pernoscenda studia liberalium artium nostro etiam quos possumus invitamus exemplo. Inter quae iam pridem universos veteris ac novi instrumenti libros, librariorum imperitia depravatos, Deo nos in omnibus adiuvante, examussim correximus.

'Thus, as our care is that the condition of our churches should always progress toward improvement, we strive to repair through alert zeal the work of learning nearly obliterated by our forefathers' idleness, and we invite those we can, also by our own example, to study in depth the Liberal Arts. Among these, with God's help in everything, we have already acutely corrected all books of the Old and the New Testament that had been corrupted by the copyists' lack of erudition.'

The main goal in the Carolingian renewal movement can be seen as a gathering of available knowledge, its pedagogic reworking and standardisation, and greater perspicuitas: ${ }^{101}$ the new Carolingian minuscule writing, the standardised Bible text, the standardised monastic rule (of St Benedict) all contributed to this end. The Carolingian renewal focused very much on Latin Antiquity, which may explain why it was not much of a scientific renewal, especially not where the natural sciences are concerned. But Charlemagne and his organisers produced the right kind of environment for further study: schools, libraries, a unified script, a standardised classical language. Leonhardt (2013: 123) sees here the beginning of a thousand years in which Latin was the indispensable language of culture and

99 More detail about his 'Renaissance' in Brown (1994). On Charlemagne see Becher (2004).

100 See Leonhardt (2013: 122) and in general Brunhölzl (1965).

101 On these aspects, see Schieffer (2010). 
science' in Europe, ending symbolically with the abdication of the last Holy Roman Emperor, Francis II, in 1806.

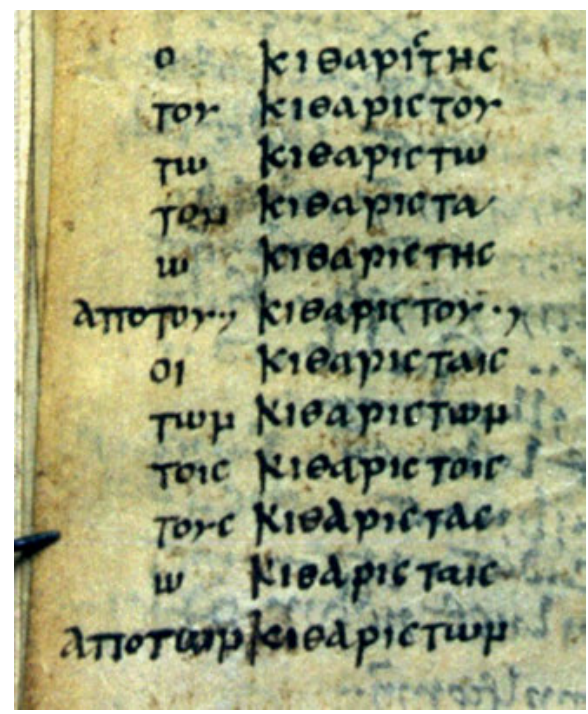

Fig. 15: Reichenauer Schulheft, detail showing Greek declension. Ms. Stift St. Paul im Lavanttal 86a/1, fol. 8v, detail.

Source: http://hildegard.tristram.de/schulheft.

Many of the promoters of these schools were Irish or Anglo-Saxon monks who came to the imperial court or to Frankish monasteries. ${ }^{102}$ Indeed, the Irish seemed to feel especially attracted to difficult studies, even including some input from Greek. ${ }^{103}$ The so-called Reichenauer Schulheft is a short, early ninth-century manuscript containing information on various fields, for instance grammar, Greek declension (see fig. 15), ${ }^{104}$ astronomical tables, and the famous Old Irish poem Pangur bán, about a white cat. Charlemagne's ideas of empire favoured the interchange of scholars in many ways. Although there was no centralised institution of

102 'Ils apportent des manuscrits, font connaître des auteurs oubliés tel Martianus Capella, redonnent vie à l'étude des sciences et de la dialectique et enfin sont les artisans du renouveau de l'hellénisme' ('They brought manuscripts, made forgotten authors such as Martianus Capella known, revived the study of science and dialectics, and were the architects of the revival of Hellenism'; Riché 1979: 92).

103 See Berschin (1980).

104 Interestingly, an extra row for the ablative case, which does not exist in Greek, is included, with the preposition óró. 
learning, there definitely was a circle of intellectuals in contact with one another and with the emperor, but these scholars often moved about and were mostly in contact by letters only. ${ }^{105}$ This web included many of the most important intellectuals of the time, such as the Franks Einhard and Angilbert, the Italian Paulinus of Aquileia, the Visigoth Theodulf, the Anglo-Saxon Alcuin, or the Irish Dungal. But the sciences were seen only as tools for a restructuring of religious life. ${ }^{106}$ Carolingian savants of this first generation improved and unified the Latin Bible text, especially Alcuin and Theodulf of Orléans (ca. 760-821). In the next generation, Rabanus Maurus (780-856) tries to replace Isidore's Etymologiae with his own reorganised and moralised De universo. Among his numerous works, there are also many Bible commentaries. His pupil Lupus of Ferrières (ca. 805-ca. 862) was an avid finder of classical manuscripts and can be seen as an early philologist. He is often quoted for saying (Epistola I.5 to Einhard, ed. Marshall, p. 2):

Mihi satis apparet propter se ipsam appetenda sapientia.

'It seems to me that wisdom is to be sought for its own sake.'

As Beeson (1930) first pointed out, in his letters Lupus often requests manuscripts of texts he already possesses in order to correct and improve their text. In the same letter to Einhard, he says (I.7, p. 3):

Tullii de rhetorica liber (quem quidem habeo, sed in plerisque mendosum [...]).

'Cicero's book on rhetoric [De oratore], which I possess but is in many passages corrupt [...].'

Several dozen manuscripts survive that contain the hand of Lupus as scribe, commentator, corrector. Michael I. Allen is currently working on a new commented edition of Lupus' letters that will shed more light on his well-developed philological method. ${ }^{107}$ In Charlemagne's entourage, a new large and alphabetical dictionary of Latin expressions, the Liber glossarum (ed. Grondeux \& Cinato), was much used. Its content goes back to Visigothic Spain. Nonetheless, Isidore's Etymologiae continue to be widely used.

The renewal survived Charlemagne, who died in 814. A group of scholars remained assembled around the imperial court of his successors, especially Charles

105 See Bullough (2004) and Veyrard-Cosme (2013) for Alcuin as a letter writer.

106 '[L]a production littéraire du viiie siècle est surtout religieuse: ouvrages liturgiques, commentaires exégétiques, droit canon, Vies de saints. Le comput et l'astronomie ne sont que des sciences auxiliaires à l'étude religieuse' ('The literary production of the eighth century is mainly religious: liturgical works, exegetical commentaries, canon law, lives of saints. Computus and astronomy were but auxiliary sciences to religious study'; Riché 1979: 111).

107 To be published in Corpus Christianorum by Brepols. 
the Bald. In this milieu, Martianus Capella and with him the Liberal Arts begin to be highly appreciated again. Walahfrid Strabo (808-849) and Florus of Lyon (ca. 810-ca. 860) are important scholars in this time, but the most outstanding one was certainly John Scotus Eriugena (810-877), who learned and translated Greek and will be treated in more detail below. Many schools in what is now northern France fostered a culture of the book and of learning across generations of masters and pupils. These schools also exchanged manuscripts and staff. ${ }^{108}$ A generation later, Remigius of Auxerre (ca. 841-908) wrote his very lucid commentary on Martianus Capella, which further established the latter's work as the basis of artes education in the centuries to follow. The Carolingian recension of Martianus' text, which improved many corrupt passages, has to be situated in his entourage. ${ }^{109}$ Remigius was not only interested in textual criticism but also wrote about content. For instance, he notes that the arithmetical terminology in Boethius sometimes differed from that of Martianus (e.g. sesqualter vs superdimidius). ${ }^{110}$ In addition, Remigius also commented Donatus' Artes, Priscian's Institutiones, Eutyches' Ars verbi, Phocas' Ars, and Bede. Riché (1979: 247) describes his way of working thus:

Il fait preuve de qualités de clarté dans une matière difficile. Il cite ces sources, confronte leurs interprétations, s’interroge sur les désaccords entre latin de grammairiens et latin biblique.

'He gives proof of the quality of clarity in a difficult matter. He quotes his sources, compares their interpretations, and questions the disagreements between the Latin of the grammarians and the Latin of the Bible.'

Imbibed in classical studies in the second generation of the renewal, a goût for Roman science emerged among these scholars - one based on the Seven Liberal Arts and Martianus Capella, who, as noted above, is quite a good representative of 'Roman science'. Practical uses were seldom far-off. For instance, astronomy is studied mostly for computistic reasons, ${ }^{111}$ and in general science remains auxiliary to theology and the functioning of the Church in this epoch. ${ }^{112}$ A closer look at the approach and language of two contrasting authors, Rabanus and Eriugena, follows.

108 The school of Laon was studied in depth by Contreni (1978); see further Contreni (1989).

109 See Guillaumin (2008: 1:204-205).

110 Commentum in Martianum Capellam, ed. Lutz, p. 213.

111 As Riché puts it: 'Le comput et l'astronomie ne sont que des sciences auxiliaires à l'étude religieuse' ('Computus and astronomy are only auxiliary sciences to religious studies'; 1979: 111). 112 For the monks' interest in learning, see Leclercq (2008). 
The more conventional and more successful of the two, Rabanus Maurus (780-856), ${ }^{113}$ wrote an encyclopaedia, De rerum naturis. ${ }^{114}$ It is a compilation mostly interested in the allegorical theological significance of things; scientia is for this author first and foremost scientia divina. Rabanus used many sources, especially Isidore. ${ }^{115}$ His Computus (edited in CCCM 44) ${ }^{116}$ is also hardly independent: it is largely based on Bede. This work is written in the form of a didactic dialogue between master and pupil. Rabanus rarely speaks about science detached from theology, but he does acknowledge its existence, although he tends to shun discussions of points that are not clear. His aims are formulated by Rissel (1976: 328-329) thus:

\begin{abstract}
Er war vielmehr einmal bestrebt, aus der Fülle der überlieferten wissenschaftlichen Literatur die ihm als zeitlos bedeutend und allgemein anerkannt erscheinenden Inhalte auszuwählen; auf der anderen Seite verfolgte er das Ziel, die aus den Quellenwerken übernommenen Ergebnisse durch Textänderung und Neukombination der Inhalte den Auffassungen, Denkgewohnheiten und geistigen Bedürfnissen der Karolingerzeit anzupassen.

'On the one hand, he endeavoured to select from the handed-down wealth of scientific literature content that seemed to him to be timelessly important and generally accepted; on the other hand, he pursued the goal of adapting the results taken from his source works to the views, thinking habits, and intellectual needs of the Carolingian period by changing the texts and recombining the content.'
\end{abstract}

In his Institutio clericorum, he tells the reader much about his approach to the sciences, which he believed to be important for future priests. His approach is similar to and inspired by Augustine's Doctrina christiana. Books I-II treat ecclesiastical matters, while book III discusses knowledge in general, for instance the Seven Liberal Arts (III.18-25). Zimpel's edition shows nicely how much of the work is made up of quotations. An excerpt that is not a quotation will suffice to illustrate Rabanus' language and approach (Institutio clericorum III.2, ed. Zimpel, vol. 2, pp. 438-439):

Fundamentum autem, status et perfectio prudentiae, scientia est sanctarum scripturarum [...]. Nec enim illa, quae in libris prudentium huius saeculi vera et sapientia reperiuntur, alii quam veritati et sapientiae attribuenda sunt, quia non ab illis haec primum statuta sunt, in quorum dictis haec leguntur, sed ab aeterno manentia magis investigata sunt, quantum ipsa doctrix et inluminatrix omnium veritas et sapientia eis investigare posse concessit.

'The foundation, the characteristic, and the perfection of prudence is the knowledge of Holy Scripture [...]. Nor are those things that are found to be true and wise in the books of the wise of this world to be attributed to something other than truth and wisdom, for they were not

113 On his very successful rôle as a teacher, see Felten \& Nichtweiss (2006).

114 Called De universo in PL 111. Unfortunately, there is no critical edition of this work.

115 Heyse (1969) studied the sources.

116 See Rissel (1976). 
first asserted by those in whose books we read them but were rather discovered as eternally self-same to the extent that truth and wisdom - that teacher and illuminator of all things allowed them to be discovered.'

As can be seen, his Latin is correct and he uses clear syntax, but he has no concerns about using rare but easily understandable words (such as doctrix, inluminatrix) ${ }^{117}$ Thus, this language seems well suited for his didactic purposes. Rabanus was most of all an important Carolingian teacher.

\$11 In contrast, John Scotus Eriug ena (810-877) was certainly the most original thinker during the Carolingian epoch, although his direct impact on his environment was at best limited. He was an Irishman who knew and translated Greek. More of a mystic theologian and conveyor of Greek patristic ideas (which were much more heavily imbibed with neo-Platonism than their Latin counterparts) and not so much a scientist, he nevertheless discusses scientific topics in some detail. Besides several translations of Greek works, his main work, the Periphy-

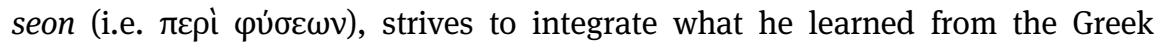
Fathers into a comprehensive mystic worldview, heavily indebted to Ps-Dionysius and Maximus Confessor. The work's form is that of a didactic dialogue between master and pupil; there are several surviving manuscripts from the entourage of its author (fig. 16).

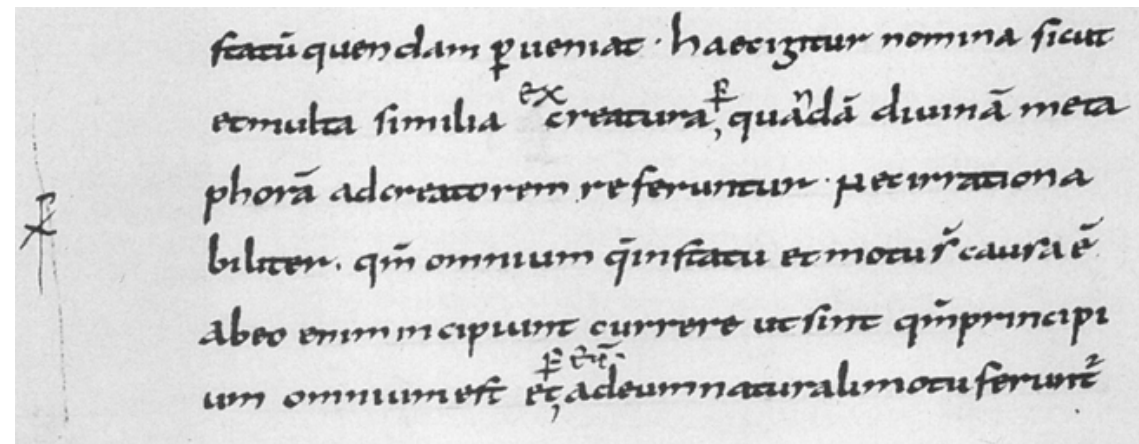

Fig. 16: Reims, Bibliothèque municipale 875 , fol. $75 \mathrm{v}$, showing Periphyseon I.12, PL 452A; one of its hands is probably Eriugena.

Source: https://commons.wikimedia.org/wiki/File:Eriugena,_Periphyseon,_Reims,_875.jpg

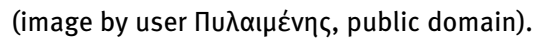

117 But both are also known from Late Antiquity according to $T L L$ (s.vv.). 
Both Eriugena's thought and his language give a foretaste of something between thirteenth-century scholasticism and Renaissance Platonist science. ${ }^{118}$ Typically for the former, the alumnus in Eriugena's dialogue occasionally demands a dialectica formula of an argument to be given (e.g. PL 491C = ed. Sheldon-Williams, vol. 1, p. 146); ${ }^{119}$ this is done in the form of a scholastic quaestio, utrum, followed by syllogisms (collectiones). In order to understand a topic, Aristotelian categories are invoked: quid sit, unde sit, ubi sit [...] (PL 449A = ed. Sheldon-Williams, vol. 1, p. 52; de theophania), or the definition of something is sought: quid [...] id est utrum sit, quid sit vel qualis sit et quomodo diffinitur (PL 455B = Sheldon-Williams, vol. 1, p. 66). Sometimes, Eriugena tries to harmonise seemingly conflicting views in authorities, as for instance (PL 446B = ed. Sheldon-Williams, vol. 1, p. 46): ${ }^{120}$

ac per hoc necessarium est nos rectam mediamque viam tenere ne vel Apostolo videamur resistere vel sententiam summae ac sanctae autoritatis magistri non obtineri. Utrumque igitur verum dixisse non dubitandum, immo firmiter tenendum.

'and therefore it is necessary that we remain on the correct middle way, in order that we neither seem to oppose the Apostle Paul nor that we will seem not to uphold the judgement of the holy authority of the master [Augustine]. It is not to be doubted that both speak the truth, nay, this is even to be firmly held.'

Nonetheless, he judges ratio to be of higher dignitas than auctoritas (PL 513B-C = ed. Sheldon-Williams, vol.1, pp.196-198), so auctoritas is only used sparingly and for those who do not trust ratio alone (PL 781C = ed. Sheldon-Williams, vol. 4, p. 96). Indeed, ratio has a very central position in Eriugena's thought: it is itself the genus of the two species wisdom and science. ${ }^{121}$ For Eriugena the difference between sapientia and scientia lies in the object and the method: while sapientia makes man approach the divine sphere and God through real intelligere, scientia understands the things below man in the cosmic order, that is, especially nature;

118 On these see respectively chaps 11 and 12 below.

119 We quote the PL column and the page in the Sheldon-Williams edition, for vol. 5 that of Jeauneau. For the other volumes, passages in the Jeauneau edition can be easily located with this information. The commented reprint of Jeauneau's main text by Peter Dronke is also helpful.

120 Similarly: Vera enim auctoritas rectae rationi non obsistit neque recta ratio verae auctoritati ('For true authority does not oppose correct reasoning, nor correct reasoning true authority'; PL 511B = ed. Sheldon-Williams, vol. 1, p. 192).

121 Rationis item duplex species arridet, una sapientia, altera scientia ('Likewise, two species of reason are pleasing: one wisdom, the other science'; PL 629A = ed. Sheldon-Williams, vol. 3, p. 48). 
its method is mere rationcinari. ${ }^{122}$ His distinction between sapientia and scientia, and their consequent equation with theologia and physica respectively, becomes clear in PL 629A-B (= ed. Sheldon-Williams, vol. 3, pp. 48-50):

\begin{abstract}
Sapientia namque proprie dicitur virtus illa, qua contemplativus animus, sive humanus, sive angelicus, divina, aeterna et incommutabilia considerat; sive circa primam omnium causam versetur, sive circa primordiales rerum causas, quas Pater in Verbo suo semel simulque condidit, quae species rationis a sapientibus theologia vocitatur.

Scientia vero est virtus, qua theoreticus animus, sive humanus, sive angelicus, de natura rerum, ex primordialibus causis procedentium per generationem, inque genera ac species divisarum, per differentias, et proprietates tractat, sive accidentibus succumbat, sive eis careat, sive corporibus adjuncta, sive penitus ab eis libera, sive locis et temporibus distributa, sive ultra loca et tempora sui simplicitate unita atque inseparabilis. Quae species rationis Physica dicitur.

'That faculty is properly called wisdom by which the contemplative mind (be it human or angelic) considers divine, eternal, and unchangeable things; whether it occupy itself with the first cause of everything, or with the first causes of things, which the Father created through his Son once and together. This kind of reasoning is called theology by the wise.

But science is the faculty by which the contemplative mind (be it human or angelic) treats about the nature of things that proceed from the primordial causes through generation into different genera and species (through differentiae), and into properties; whether this faculty yield to accidents, or lacks them, whether joined with bodies, or completely free from them, whether distributed over space and time, or beyond space and time, one by its simplicity and inseparable. This kind of reasoning is called physics.'
\end{abstract}

Thus, scientia studies everything except God and the causae primordiales, which as a kind of first emanation from the fully transcendent God are responsible for the creation of everything. During the return (reditus) of everything to God - a theologically controversial topic - scientia and sapientia will be reached one after the other before the final union with God. ${ }^{123}$ Eriugena divides sophia into

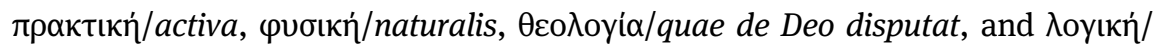

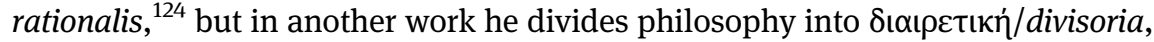

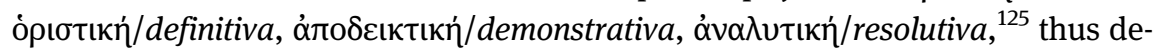
ductive, definitory, demonstrative, and analysing philosophy. While the first division is based on the topics treated (practical life, nature including narratio istorica

122 Schneider (1921: 67-68). It is interesting to note that modern mystics like Aldous Huxley (cf. 1955) also make such a distinction between more than rational deep 'understanding' (= sapientia) and mere rational/scientific 'knowledge' (= scientia).

123 Periphyseon PL 1020D, V.39, ed. Jeauneau, vol. 5, p. 225: transitus animi in scientiam omnium, quae post Deum sunt ('the transition of the soul to knowledge/science of everything that is after God').

124 Periphyseon PL 705B = ed. Sheldon-Williams, vol. 3, p. 222.

125 De praedestinatione PL 122.358A. 
(PL 705C = ed. Sheldon-Williams, vol. 3, p. 222), divine things, with the fourth type studying the methodology of the others, ${ }^{126}$ the second division is made exclusively according to the methods used. No source for either division is known to me; Eriugena seems, as often, to go his own way. ${ }^{127}$ He is much less concerned with worldly scientia than with theological sapientia, as can be gleaned from his treatment of 'physical' questions in Periphyseon III (in an excursus from PL 715D-726A = ed. Sheldon-Williams, vol. 3, pp. 244-270, about the size of the universe): he calculates using a value for $\pi$ of 2 (PL 720A = ed. Sheldon-Williams, vol. 3, p. 254), and in general he is content with referring to the opinions of others, ${ }^{128}$ though the importance of definition is clearly seen and often used (e.g. PL 651A = ed. Sheldon-Williams, vol. 3, p. 100; a definition of arithmetica).

As might be expected, his language is strongly influenced by Greek. ${ }^{129}$ The large number of Greek words that are explained and then used in his main work, the Periphyseon, shows that the rich neo-Platonist language had not yet been assimilated to Latin. The usual suspects - Greek words that are notoriously difficult

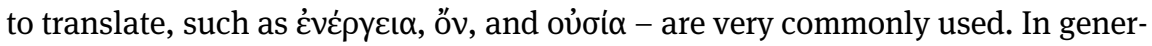
al, there seem to be three groups of other Greek words: some are used in etymologiae $^{130}$ Eriugena probably takes from the Greek Fathers (e.g. $\alpha \omega \omega \tau \rho \circ \pi i \alpha$ to explain $\alpha \nu \theta \rho \omega \pi(\varepsilon)$ í $\alpha$; PL 941D, V.31, ed. Jeauneau, vol. 5, p. 114); there are a few compounds that are hard to translate, thus 'terminological Greek'; ${ }^{131}$ and there is an

126 Periphyseon PL 705B = ed. Sheldon-Williams, vol. 3, p. 222: ostendit quibus regulis de unaquaque trium aliarum sophiae partibus disputandum ('it shows by which rules of each of the other three parts of wisdom one has to discuss'). See Sheldon-Williams's commentary, p. 319.

127 Dronke, edition, ad loc. (vol. 3, p. 391) considers Origen (In Canticum canticorum, ed. Baehrens, p. 75) for the former: Generales disciplinae quibus ad rerum scientiam pervenitur, tres sunt, quas Graeci ethicam, physicam, enopticen [i.e. epopticen] appellarunt; has nos dicere possumus moralem, naturalem, inspectivam. Nonnulli sane apud Graecos etiam logicen, quam nos rationalem possumus dicere, quarto in numero posuerunt ('The general disciplines with the help of which one reaches knowledge [scientia] of things are three, the Greeks called them ethics, physics, and epoptics [theology]; we can call them [in Latin] moral, natural, and inspective [science]. Some of the Greeks, indeed, add logic, which we can call rational [science], as a fourth in number').

128 Eriugena is sometimes credited with a (nearly) heliocentric worldview, in which Mercury, Venus, Mars, and Jupiter (but not Saturn) revolve directly around the Sun (cf. PL 698A = ed. Sheldon-Williams, vol. 3, p. 206). But the fact that the topic is discussed in a mere clause, and that Saturn is not included, makes it seem that this was not a topic of great importance to him, and the system was forgotten until Tycho Brahe invented a similar one.

129 His innovative philosophical vocabulary is studied by Jeauneau (2000).

130 See chap. $21 \S 7$ below.

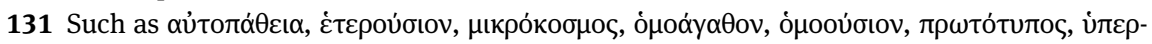

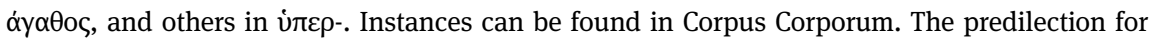

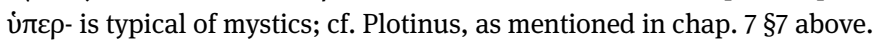


amazingly large group of Greek words for which there have been Latin equivalents at least since the time of Boethius but which Eriugena seems to retain in order to give the text a Greek 'flavour': Eriugena is a typical user of ornamental Greek. ${ }^{132}$ Besides, he uses many naturalised Greek words such as dogmatizare. John also follows in the Areopagite's footsteps concerning language: he creates words such as superessentialis, or marks new differentiations with suffixes. The later scholastic trend of nominalising concepts with suffixes can be observed quite often: numerositas as 'number-ness', superessentialitas et supernaturalitas,

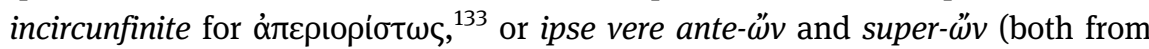
Eriugena's translation of Dionysios, De divinis nominibus). Such words, however, reflect more the mystic who tries hard to say the inexpressible than a scientist who sets out to name newly discovered things.

With Eriugena, it could have seemed that Greek thought would enter Western Europe again, but his major work, containing a complete philosophico-theological worldview, ${ }^{134}$ was not received very favourably. The time was not yet ripe for the re-uptake of Greek science in Latin Western Europe. The work gained a reputation of obscurity: although Eriugena did influence some other Carolingian scholars, especially Heiric and Remigius of Auxerre, ${ }^{135}$ neither his neo-Platonist worldview nor his habit of reading Greek sources and incorporating their thought established themselves in Carolingian times - maybe due to the lack of bilingual scholars other than himself. His major work was occasionally used by writers interested in physica, especially in the twelfth century, for instance by Honorius Augustodunensis (in his Clavis physicae) ${ }^{136}$ and possibly some of the authors of the Circle of Chartres (see chap. 10 below), but when followers of the heretic Amalricus of Bena (d. 1204) used it to support their pantheism, the work was condemned by Pope Honorius III in 1225 with vile words: as being totus scatens vermibus heretice pravitatis ('all swarming with worms of heretical depravity'). ${ }^{137}$ The work was largely forgotten (with the notable exception of Nicolas of Cusa and possibly Raimundus Lullus) ${ }^{138}$ until its editio princeps in 1684 by Thomas Gale, after which it duly found its way into the index librorum prohibitorum, despite the fact that its

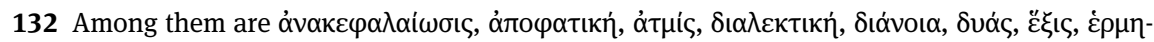

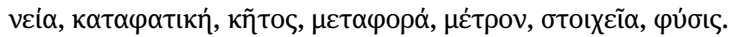

133 Translating Dionysius, De divinis nominibus I.7, ed. Suchla, p. 120.

134 The first such work in Latin, according to Riché (1979: 116).

135 See O’Meara (1988: 205-212). See also Dräseke (1908).

136 See O’Meara (1988: 216-219).

137 Regesta pontificum romanorum, ed. Potthast, vol. 1, p. 634.

138 See Yates (1960). 
philosophical position is very close to that of Ps-Dionysius. ${ }^{139}$ The Heiric of Auxerre just mentioned was a pupil of Lupus: the Carolingian intellectuals formed a web of scholars who knew of one another's activities and shared ideas, manuscripts, and pupils among their Carolingian schools in a way unseen since Roman times.

\$12 In the later ninth and in the tenth century, in the so-called saeculum ferreum, ${ }^{140}$ the Carolingian renewal slowly lost impetus, although many monastic schools and centres continued to operate. Saracen, Viking, and Magyar incursions devastated many monasteries. The tenth century is also noted for its immoral popes and their mistresses (the 'pornocracy'). Only since 1990 has the literature of this period received a justified, more positive treatment, thanks to a congress organised by Walter Berschin. ${ }^{141}$ In this time, the education of laymen moved from monastic schools to cathedral schools, which would remain important centres of learning for several centuries. Among them were Barcelona, Vich, Reims, Cologne, Trier, and Liège. The monastery of Cluny was also founded in this time (in AD 910), 'in einer fast herrschaftslosen Region und zudem an einem kaum zu steigernden Zeitpunkt der Zersetzung klösterlichen Lebens' ('in a region almost devoid of government authority and, moreover, at a time when monastic life decomposed in a way that could hardly be increased'; Melville 2012: 56). Here began a monastic reform movement that was to grow all over Latin Europe in the subsequent two centuries. The main reasons for its success were independence from the local land-owners (Cluny was directly subordinate to the Pope), the free election of its abbot by the monks, ${ }^{142}$ and the fact that Cluny's daughter foundations were founded as priories dependent on Cluny. This produced a Cluniac network all over Latin Europe in which books and ideas could and did move quickly. But, of course, science was not among the core interests of the Cluniacs, who were first and foremost a liturgical movement. The second abbot, Odo, was a pupil of Remigius of Auxerre, again showing the interconnectedness of the Carolingian intellectuals.

The man most interested in theoretical knowledge in these times was certainly Gerbert of Aurillac (ca. 945-1003). ${ }^{143}$ He encountered Arabic sources in the Catalan monastery of Ripoll, where he stayed three years. Ripoll was at that

139 Ps-Dionysius was protected from being made a heretic by his fictitious apostolic authority. 140 Also saeculum obscurum; these names go back to Baronius (1538-1607), who used them to designate the crisis of the papacy in these times.

141 Proceedings published in Berschin (1989/1990).

142 Usually, abbots were chosen by the local lay nobility.

143 See Riché (1987); Stoppacci (2016). 
time in close contact with al-Andalus, which saw a second heyday of science, learning, philosophy, and literature under Caliph 'Abd al-Rahman III (891961). ${ }^{144}$ Later in life, Gerbert taught in Reims, wrote works about mathematics, and edited Boethius' scientific works. His main interests lay in the quadrivium: he built astrolabes and abaci and wrote about them. ${ }^{145}$ These studies do seem to have met with some interest; we know, for instance, of a case of a magister who exchanged a Statius manuscript for one of Gerbert's scientific instruments. ${ }^{146}$ Remarkably, his interests were of a theoretical - scientific - not a practical type. His style betrays the influence of Cicero's orations and those of the late antique orator Aurelius Symmachus, texts that were hard to find in Gerbert's time. For the last four years of his life, he held office as Pope Silvester II. For his unusual erudition and rapid social ascent, he acquired a reputation of being a magician about half a century after his death; he did not find many followers until things changed in the twelfth century. Nonetheless, at least some disciples of Gerbert are known, such as the historian Richer and a Constantinus of Micy, and Gerbert can now be situated within his time quite well: ${ }^{147}$ he was not as much a lone figure too early for his time, as he was sometimes seen in the past. For instance, his contemporary Abbo of Fleury (ca. 945-1004) also studied logic, computus, and the quadrivium. ${ }^{148}$

In the late tenth and eleventh centuries, we know of at least the following schools that taught the quadrivium: St Gall, Reichenau, Liège, Fleury, Chartres, and Reims. ${ }^{149}$ In particular, the use of hitherto unknown instruments - the astrolabe and abacus - made much more precise time measurement possible. ${ }^{150}$ Among the forerunners of the twelfth century was the 'monastic scientist' Hermann of Reichenau (1013-1054), called Contractus for being lame. Among other things, he wrote about the use of the astrolabe, on music theory, and a remarkable world chronicle. ${ }^{151}$ Manitius calls him 'einer der größten Gelehrten des Mittelalters' ('one of the greatest scholars of the Middle Ages'; 1911-1931: 2:756). He appears to have had some pupils, such as Meinzo of Constance (786-787). Somewhat later, Wilhelm, abbot of Hirsau (ca. 1030-1091), made relatively precise as-

144 Samsó (1992: chap. 2). The first was under 'Abd al-Rahman II (792-852). Unfortunately, the library of Ripoll was destroyed in 1863.

145 On his erudition in the mathematical sciences, see Lindgren (1976).

146 Cf. Epistolae 134, 148, ed. Riché \& Callu, pp. 328, 362.

147 Riché (1985: 68).

148 See Obrist (2004). On the use of diagrams in Fleury and Chartres, see Guerrini (2016: 33-39).

149 Riché (1979: 276). Gerbert taught the Liberal Arts in Reims.

150 See Bergmann (1985).

151 Germann (2006). See Borst (1984) for 'monastic science'. 
tronomical measurements. ${ }^{152}$ In general, the mathematical sciences started to become en vogue again in the eleventh century. Another instance is Franco of Liège (ca. 1020-1083), who attempted the quadrature of the circle. He made his task easy by assuming $22 / 7$ to be the ratio between the circumference and diameter of the circle (i.e. $\pi$ ).

Similarly in medicine, some outstanding medical authors are already found in the eleventh century at the Medical School of Salerno; ${ }^{153}$ two of them are known well enough to trace their personalities: Gariopontus (fl. in the second quarter of the eleventh century) and Constantinus Africanus (ca. 1020-1087). The latter was important as a translator (see chap. 10 §5), but the former reworked much of the then known Latin medical tradition and produced a new compendium: the Passionarius, ${ }^{154}$ a very successful work (at least sixty-five manuscripts are known) despite the fact that it still lacked the new Arabic material that was soon to be translated into Latin. Compared to its early mediaeval predecessors, the Latin and the organisation of the material are much improved. Even after translations of medical works from Arabic and Greek became widespread, the Passionarius was still frequently copied. It was even printed several times in the fifteenth and sixteenth centuries. Its content was apparently not seen as outdated by the translations.

These examples show that in many scientific fields, important novelties already appear in the eleventh century, preparing the way for what might be called an intellectual revolution in the twelfth century; other fields would follow suit up to the middle of that century, as will be shown in the next chapter. The twelfthcentury 'scientific revolution' 155 was equally slow, but also at least equally profound, as that in the sixteenth and seventeenth centuries.

\section{Relation to criteria for science}

\$13 From this sketch of scientific activity in Christian Late Antiquity and the Early Middle Ages (before the long twelfth century) in Latin, one gets the impression that it does not compare so badly with similar activities during the epoch treated in the previous chapter. Indeed, for technology it has now become established fact how far the times of the Carolingian renewal surpassed the Romans in many fields: they made important advances in agriculture, heating, and other fields, in-

152 See Wiesenbach (1991: 125-128).

153 On the school, see Jacquart \& Paravicini Bagliani (2007); Kristeller (1986).

154 On which see Glaze (2009). She intends to edit the text. The Lugduni, 1526 edition can be read online at https://www.e-rara.ch/zuz/content/titleinfo/9400142.

155 On the validity of such a term, see chap. $13 \S \S 1-3$. 
cluding the invention of completely new devices and materials such as borax and salmiak as flux in soldering (ca. 800). Technological advances continue in the later Middle Ages - e.g. mechanical clocks, ca. 1300 - making it clear that the Middle Ages were by no means an age of technological stagnation. ${ }^{156}$ In more theoretical scientific matters, the picture may be somewhat less positive, although we must take care not to see the times before the twelfth century through the eyes of the time after it, as the Denkstil was different.

Latin scientific activities (in a broad sense) may be summarised as having had their central focus move away from rhetoric toward theology among Christians, but the approach to science and learning does not seem to change much between Late Antiquity and the eleventh century. The central outlook is encyclopaedic and traditional; innovation is by and large innovation by newly combining known 'facts', creative imitation, and recomposition. ${ }^{157}$ This is why Late Antiquity has been called the age of résumés (§1 above). Another trait of both parts of this epoch is that the Seven Liberal Arts are often used as the classification scheme for science and learning. This scheme dates from Late Antiquity: there was no standard division of science and learning in Hellenistic and early imperial times. The next chapter will show how new approaches gradually replaced this overly rigid and narrow scheme in the twelfth century.

Of course, the long epoch studied in this chapter does still fall quite naturally into two blocks separated by the barbarian invasions that ended the Western Roman Empire. As, however, the cultural decline was of very variable speed, rather little time passed between the last exponents of Roman education (such as Isidore, d. 636) and the first signs of the Carolingian renewal (such as Bede, b. 672) - reducing the core of the 'Dark Ages' to a generation or two. In Carolingian times, the renovation was not most notably a scientific one: on the one hand, Christian learning and practice was renovated, standardised, and approached in a more scholarly way; on the other hand, antique Roman culture was renewed, and with it its Handbuchwissenschaft. In all of this, the didactic aspects usually outweighed proper scientific curiosity, as we have seen in the example of Rabanus Maurus. Similarly, the scientific interests of Bede were subjugated to his spiritual interests. Even the apparent exception Eriugena was a mystic theologian with a very limited interest in science beyond its use as an auxiliary enterprise. Things only change with Gerbert - who should in fact rather be seen as a forerunner of the twelfth century - as well as with some scholars of the eleventh century.

156 See Hägermann \& Schneider (1991: esp. 322); Lindgren (1996: 198-204 on soldering, 391-398 on mechanical clocks).

157 Cardelle de Hartmann (2015: esp. 365-366) speaks of 'kreative Imitation' in the context of the poetess Hrotsvit of Gandersheim, but the term applies well to the general culture of this time too. 
The language of the authors treated here is in general much less rhetorically coloured than that of 'classical' authors such as Cicero or Seneca. A didactic approach and perspicuitas seem to be of greater importance to most of them. Accordingly, the rhetorical disdain for coining new words diminishes, and would continue to do so until Renaissance classicists wanted to turn the clock back to Ciceronian times. Among early Latin Christians, Tertullian, Augustine, and Jerome in particular paved the way for mediaeval Christian Latin and its greater openness to novel ways of expression compared to classical rhetorical Latin. They thus fulfilled an important rôle as language innovators; but in addition to this, the formulation of Christian dogma in the fourth and fifth centuries - the most palpable expression of the Christian Denkstil - can also be likened to a scientific process fulfilling surprisingly many of the above criteria (chap. 4, §5): in these discussions about the nature of God, the Trinity, Christ, and their relationship to the created world, which were often held at oecumenical councils ('international conferences'), there definitely was a community effort (V); the results were condensed into highly formalised statements such as the Creed (VI); and clear, unambiguous terminology (ii) was sought and fought for (compare e.g. the term ónoov'бเo૬). There is definitely a systematic method (I) based on the study of Holy Scripture and the experience of saints and mystics. There was also a coherent system (IV), largely based on biblical studies and their auxiliaries; the topics are well defined. We have met some (mostly monastic) centres where a community of scholars worked and passed their approaches on to the next generation (V). The theological superstructure that was its product and is still the doctrinal basis of all Christian groups accepting Chalcedon (AD 451) today, was a coherent and fruitful way (IV) of thinking about God and the world. As the enormous amount of Christian theological literature intimates, it led to a Christian Denkstil that characterised the mediaeval world in which modern science as a society-wide phenomenon originated. Of course, from today's point of view, we may perceive a lack of testability and step-by-step explanations (II), and a rather arbitrary choice of accepted Scripture as its bases, besides the not-impartial (III) influence of politics at many of the councils, ${ }^{158}$ as reasons not to consider the formation of Christian dogma as a scientific process. But testability has only recently become of fundamental importance, and many other sciences in Antiquity were quite lacking in it as

158 A good example is the Council of Ephesus (AD 431) and Cyril of Alexandria's machinations. But the influence of politics can still be a hindrance to scientific understanding today. There were conspicuous examples in the Soviet Union where Marxist principles were not allowed to be contradicted (e.g. Lysenko vs Darwinian evolution), and even today certain creed topics cannot be studied scientifically (e.g. a possible link between human groups and mental traits) because they do not fit into the current political agenda. 
well. ${ }^{159}$ Below, we shall see that theology becomes the paradigmatic science in scholastic times. Among the auxiliary sciences cultivated within this Christian Denkstil, computus in particular, producing an accurate world chronology, can fulfil further criteria by explaining step-by-step (II) and sometimes by being testable and impartial (III), although strictly disinterested studies reaching the rigour of Greek science are lacking. On the whole, formalisation (VI) can be seen as the weakest point in this epoch; moreover, the linking of criteria II (observation) and III (explanation) was weak: the entire epoch clearly cannot stand up to comparison with antique Greek science, but as much science as was cultivated had in nearly all cases strong Greek roots. Even the new Christian Denkstil largely developed in Greek, and was then taken over more fully than in other fields in the Latin world. Other 'learning' is comparable to non-Greek learning in other highly developed cultures: the key Greek interplay of open and unbiased observation and explanation is very rarely seen in Latin before the twelfth century with its return of the Greek Denkstil.

It is interesting to note in passing that during the time of the Carolingian renewal, Greek scientific texts were translated into Syriac and soon further translated into Arabic: something that was not yet happening in the Latin world. This enterprise was begun under Caliph Hārūn al-Rašìd around AD 800 and continued under his son al-Ma'mūn. The precise rôle of the caliph and his library, the House of Wisdom (bayt al-hikma), in this process is debated. ${ }^{160}$ The adoption of Greek learning led to significant scientific and technological advances in the Arabicspeaking empire, which were to bear fruit over several centuries. ${ }^{161}$ The Arabs differentiated religious sciences ('ulūm al-qur'ān or al-'arab, later usually 'ilm alkalām), ${ }^{162}$ required to study, recite, and expound the Quran, from the sciences of the ancients ('ulūm al-awā'il). The 'ancients' were mostly the Greeks, although the Arabs did not eschew learning from Indians, Persians, and Latins in some cases. ${ }^{163}$ Especially in al-Andalus, there are traces of Arabic reception of preconquest Latin studies. ${ }^{164}$ The Syriac and Arabic translators had to solve similar linguistic problems to those facing their Latin colleagues - and indeed also more difficult ones, as their target language was not at all related to Greek and had lim-

159 And it is still very much debated what testability is sufficient; consider the replication crisis in human and medical sciences that is currently unfolding (Ioannidis 2005; chap. 4 §8 above).

160 On the sources for the House of Wisdom, see Balty-Guesdon (1992); on other scientific institutions as well, see Micheau (1997).

161 See the introductions in Endress (1982-1992: 3:chap. 8).

162 e.g. al-Fārābī, De scientiis 3, ed. Palencia.

163 Finer classifications of the sciences of the ancients are studied by Jolivet (1997: 255-270).

164 Samsó (1992: 41-43). See also Vernet \& Samsó (1997). 
ited possibilities for coining new words (see chap. 22 below). Jacquart (1994) discusses interesting cases of neologisms in several different sciences in Arabic. The blossoming of the sciences in Arabic between the ninth and the thirteenth century shows the translators' success. ${ }^{165}$ Much Arabic science and lore was to be translated into Latin in the twelfth century (see chap. 10 \$5).

165 See Rashed (1997). 